Article

\title{
Investigating the Impact of Economic Uncertainty on Optimal Sizing of Grid-Independent Hybrid Renewable Energy Systems
}

\author{
Mostafa Rezaei ${ }^{1}$ D, Udaya Dampage ${ }^{2, *(\mathbb{D}}$, Barun K. Das ${ }^{3}$, Omaima Nasif ${ }^{4}$, Piotr F. Borowski ${ }^{5}$ \\ and Mohamed A. Mohamed 6,7,*(D)
}

1 Queensland Micro and Nanotechnology Centre, Griffith University, Nathan 4111, QLD, Australia; mostafa.rezaei@griffithuni.edu.au

2 Faculty of Engineering, Kotelawla Defence University, Kandawala Estate, Ratmalana 10390, Sri Lanka

3 Department of Mechanical Engineering, Rajshahi University of Engineering \& Technology, Rajshahi 6204, Bangladesh; bkdas@me.ruet.ac.bd

4 Department of Physiology, College of Medicine and King Khalid University Hospital, King Saud University, Medical City, P.O. Box 2925, Riyadh 11461, Saudi Arabia; onasif@ksu.edu.sa

5 Institute of Mechanical Engineering, Warsaw University of Life Sciences, 02-787 Warsaw, Poland; pborowski@autograf.pl

6 Electrical Engineering Department, Faculty of Engineering, Minia University, Minia 61519, Egypt

7 Department of Electrical Engineering, Fuzhou University, Fuzhou 350116, China

* Correspondence: dampage@kdu.ac.lk (U.D.); dr.mohamed.abdelaziz@mu.edu.eg (M.A.M.)

check for updates

Citation: Rezaei, M.; Dampage, U.; Das, B.K.; Nasif, O.; Borowski, P.F.; Mohamed, M.A. Investigating the Impact of Economic Uncertainty on Optimal Sizing of Grid-Independent Hybrid Renewable Energy Systems. Processes 2021, 9, 1468. https:// doi.org/10.3390/pr9081468

Academic Editor:

Enrique Rosales-Asensio

Received: 7 July 2021

Accepted: 12 August 2021

Published: 23 August 2021

Publisher's Note: MDPI stays neutral with regard to jurisdictional claims in published maps and institutional affiliations.

Copyright: (c) 2021 by the authors. Licensee MDPI, Basel, Switzerland. This article is an open access article distributed under the terms and conditions of the Creative Commons Attribution (CC BY) license (https:// creativecommons.org/licenses/by/ $4.0 /)$
Abstract: One of the many barriers to decarbonization and decentralization of the energy sector in developing countries is the economic uncertainty. As such, this study scrutinizes economics of three grid-independent hybrid renewable-based systems proposed to co-generate electricity and heat for a small-scale load. Accordingly, the under-study systems are simulated and optimized with the aid of HOMER Pro software. Here, a 20-year average value of discount and inflation rates is deemed a benchmark case. The techno-economic-environmental and reliability results suggest a standalone solar/wind/electrolyzer/hydrogen-based fuel cell integrated with a hydrogen-based boiler system is the best alternative. Moreover, to ascertain the impact of economic uncertainty on optimal unit sizing of the nominated model, the fluctuations of the nominal discount rate and inflation, respectively, constitute within the range of $15-20 \%$ and $10-26 \%$. The findings of economic uncertainty analysis imply that total net present cost (TNPC) fluctuates around the benchmark value symmetrically between $\$ 478,704$ and $\$ 814,905$. Levelized energy cost varies from an amount $69 \%$ less than the benchmark value up to two-fold of that. Furthermore, photovoltaic (PV) optimal size starts from a value $23 \%$ less than the benchmark case and rises up to $55 \%$ more. The corresponding figures for wind turbine (WT) are, respectively, 21\% and 29\%. Eventually, several practical policies are introduced to cope with economic uncertainty.

Keywords: economic uncertainty; hydrogen-based fuel cell; hydrogen-based boiler; electricity and heat co-generation; standalone hybrid renewable-based systems

\section{Introduction}

Energy acts as the foremost ingredient of thriving macro- and micro-economies in the world. In spite of this crucial role of energy in the communities, there have been controversial views, discussions, and debates surrounding the way that energy is yielded. This is due to the fact that conventional methods of electricity generation have long caused major damages to the environment, accordingly leading to the deteriorating issue of climate change [1,2]. As such, viable alternative means and environmentally benign solutions of energy production, by which the detrimental impacts can be alleviated to a very low level, have been introduced and implemented over the past few decades [3,4]. Among several methods available to generate clean, sustainable, and renewable energy, wind turbine (WT) and photovoltaic (PV) systems have been the most appealing ones and have been 
applied worldwide in suitable regions, mostly owing to the merits of cost-effectiveness, zero-or low-carbon emissions, and mature industry [5-9]. Apart from the aforementioned benefits of utilizing renewables, all nations should consider that the global energy demand is projected to touch the value of 38,700 TWh by the year 2050 [10]. This colossal amount of required energy implies and urges that the exploitation of renewables is of utmost prominence and priority.

The main shortcoming of renewables is the inherent issue of intermittency which can considerably decline the reliability of renewable-based systems. Fortunately, the concept of hybrid renewable energy (HRE) solutions has solved the problem to a great extent. Besides, HRE systems may impose less costs compared to single-source energy generation systems [11-13]. Further, to raise the reliability and also lessen the power outage, they are usually coupled with energy storage units such as a diesel generator (DG), a battery, and a fuel cell (FC) [14]. Few critical drawbacks, such as high operational and maintenance cost and harmful effects to the environment, are associated with DG power plants $[15,16]$. Among two other above-mentioned backups, FC can constitute an environmentally sustainable solution if the required hydrogen $\left(\mathrm{H}_{2}\right)$ is provided by renewable means.

One step towards the blueprint for energy security, decarbonization, decentralization of energy sector, fulfilment of the Paris Agreement emissions targets, and sustainable energy production is to electrify remote island regions using autonomous renewable-based power generation plants. Hence, if this step is taken, then the growth of the nation and high living standards of those areas can be guaranteed [17]. These places usually suffer from frequent power shortages and are very vulnerable to disruptions due to their far-off location and high dependency on fossil fuel power sites. Additionally, connecting them to the national grid will impose significant expenses linked to either capital or regular maintenance and review costs $[18,19]$. Therefore, harvesting renewable resources of energy existing in the vicinity of these communities can noticeably aid corresponding countries in terms of reaching sustainable energy development. However, optimal design of HRE systems will remain a big question which requires a careful and thorough investigation. In this regard, the very first step, and the most important, is to conduct the techno-economic feasibility studies in order to avert any losses and to minimize the potential risks [20].

In this study, three configurations for a grid-independent HRE system comprising PV, $\mathrm{WT}$, renewable $\mathrm{H}_{2}$-based $\mathrm{FC}$, renewable $\mathrm{H}_{2}$-based boiler, natural gas (NG)-fueled boiler, and biomass generator (BMG) are scrutinized to ascertain optimal sizing and their technoeconomic performance for co-supplying a touristy village, Mesr in Isfahan province of Iran, with electricity and heat. To increase sustainability and efficiency of the proposed models, the excess electricity is sent to electrolyzer for generating $\mathrm{H}_{2}$. Then, during the times when solar and wind electricity cannot meet electric and thermal demands, this stored renewable $\mathrm{H}_{2}$ is utilized to react with oxygen $\left(\mathrm{O}_{2}\right)$ for electricity generation. This transition occurs in a electrochemical process within FC-engaging electrodes and electrolytes, releasing water as a by-product [21]. This effective usage of the surplus electricity implies the necessity of adding FC to the system, otherwise a great deal of electricity would be dumped without ever being exploited [22]. Additionally, in each of other two proposed systems, it is supposed that boiler consumes renewable $\mathrm{H}_{2}$ or $\mathrm{NG}$ for meeting thermal energy demands. Furthermore, to comprehensively examine the available resources in the area, a HRE system, which includes a BMG, is investigated. Finally, among these three systems, the most suitable one, with respect to technical, economic, environmental, and reliability aspects, is selected to be further analyzed under economic uncertainty.

Due to the volatile nature of economy in developing countries, unpredictable high fluctuations are likely to happen in the discount rate and inflation. For this reason, the study looks into the effect of economic uncertainty on optimization and economics of the chosen system in such countries. To this end, the fluctuations in the nominal discount rate and inflation are considered based on a 20-year average from mid-2000 to mid-2020, as represented by Ref. [23], which are in the range of $15-20 \%$ and $10-26 \%$, respectively. 
Figure 1 illustrates the waves of the nominal discount rate and inflation in Iran during the above-mentioned period.

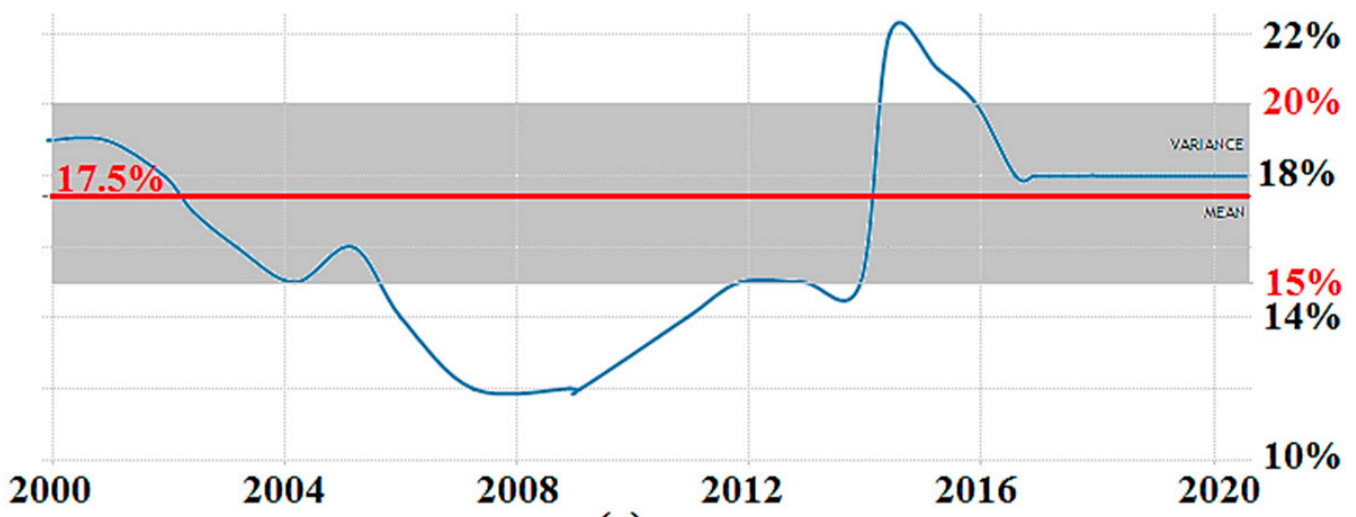

(a)

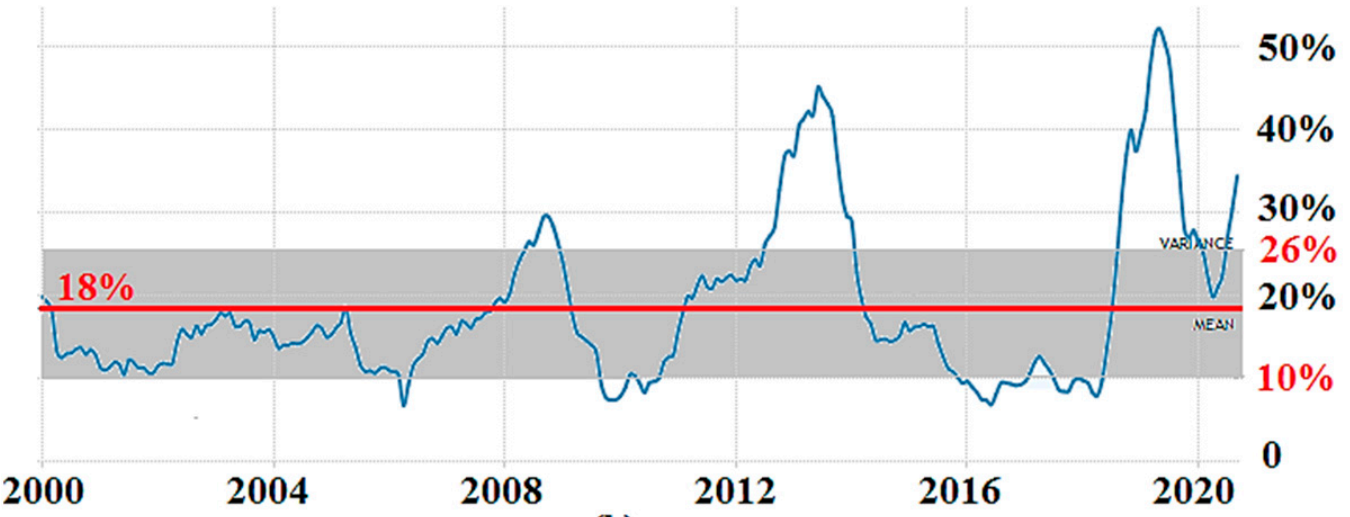

(b)

Figure 1. The fluctuations in (a) the nominal discount rate and (b) inflation from mid-2000 to mid-2020.

The main contribution of this study is that the proposed approach to optimal unit sizing of an HRE system to be applied in remote rural areas under economic uncertainty, which is inherent mostly in under-developed countries, can be deployed by other similar nations with islands and far-off villages. Additionally, a rigorous survey of literature has indicated that the the impact of economic uncertainty on optimal unit sizing of HRE systems has not been explored, which means this work could be a marked contribution to the field. Thus, interested researchers can undertake the approach of this study (Figure 2) as a guideline to scrutinize the potential of electricity and heat co-generation in the nominated regions, as well as to optimally size the units when economy is volatile. The benefits of such a scheme include (I) making the remote places self-sufficient in energy generation, (II) decentralizing electricity coverage, and finally (III) accelerating decarbonization of energy sector set to meet the Paris Agreement targets. 


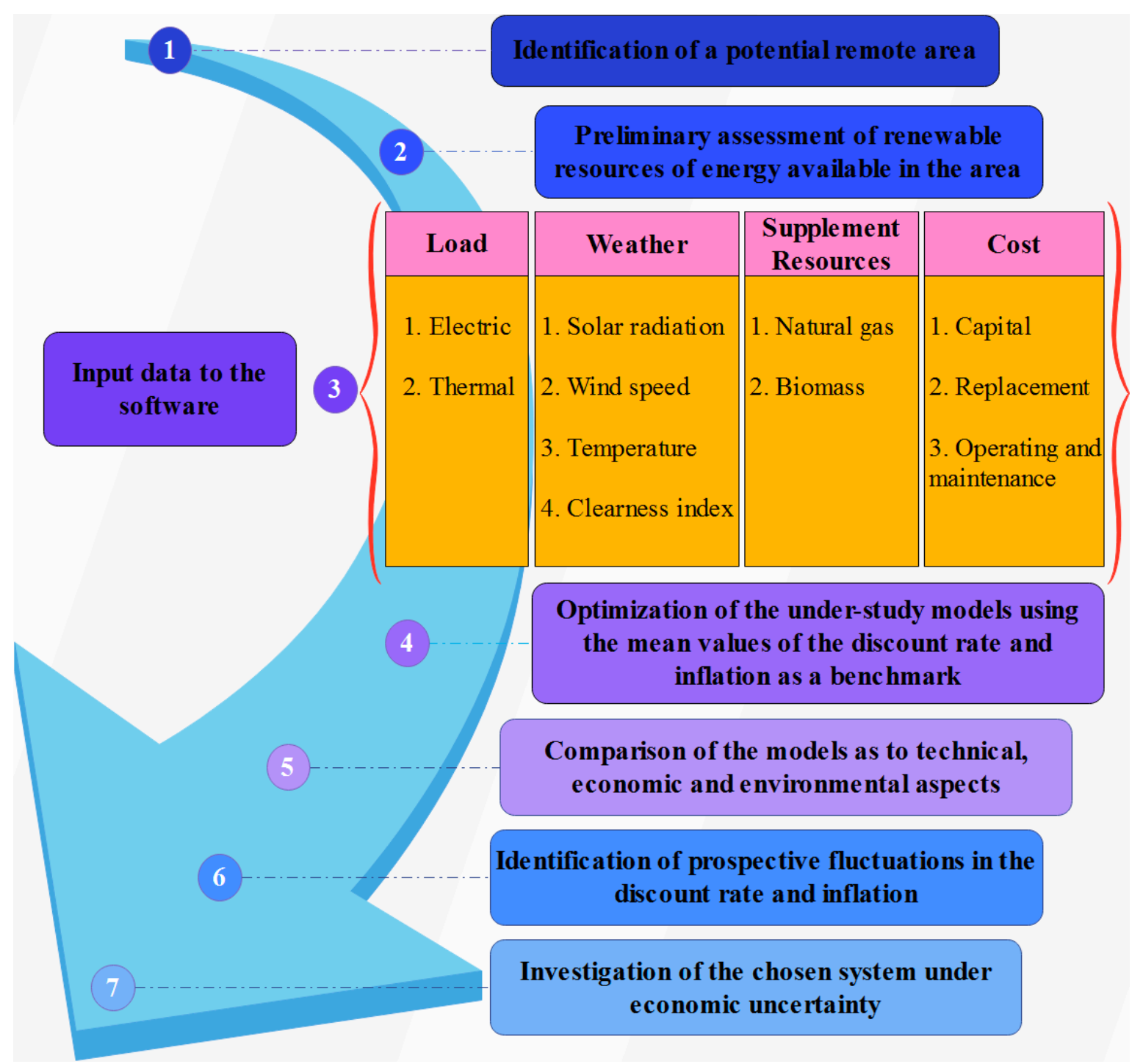

Figure 2. The approach of the study.

\section{Literature Review}

In terms of incorporating economic uncertainty into the process of configuration of an off-grid HRE system, a thorough survey of literature has demonstrated that economic uncertainty has not yet been investigated for optimal sizing of units for electricity and heat co-generation. Nonetheless, some studies have examined the influence of uncertainty associated with other aspects of renewable-related projects; the most recent ones are as follows. The impact of economic policy uncertainties on energy-growth-emissions nexus was assessed for countries regarding the application of renewable and non-renewable energy resources [24]. Furthermore, the difference in the impact of economic policy uncertainty on the investment of traditional and renewable energy enterprises was studied by [25]. Uncertainties in wind velocity, solar radiation, water flow speed, load demand, and electricity price were investigated for planning a stand-alone renewable energy-based micro-grid [26]. Bouchekara et al. [27] utilized a multi-objective approach to optimally configure an HRE system consisting of PV, WT, and DG for a micro-grid under load uncertainty. Blazquez et al. [28] scrutinized how policy instruments would work under different market conditions when considering the impact of price volatility and uncertainty of investments. Ebrahimi et al. [29] explored the uncertainty of renewable energy resources on optimal design of a multiple form energy in the presence of electric vehicle charging stations and the impact of this. 
Similarly, Li et al. [30] performed an economic analysis on micro-grids considering renewable energy uncertainty. In another research, a model was proposed for distributed generation expansion planning problem from the viewpoint of private investors considering uncertainties of renewable generations [31]. Mirzamohammadi et al. [32] also investigated the role of renewable resources uncertainty for energy supply planning for greenhouse farming. Further, the role of uncertainty in wind and solar power was evaluated for power grid peak shaving [33]. Optimal operation of a combined cooling, heating, and power micro-grid system was studied under the impact of wind power output uncertainty using an improved two-stage robust optimization model [34]. Likewise, the potential risk and benefit of complementary operation of a large PV/WT/hydropower system were assessed under the consideration of forecast uncertainty in wind and solar power [35]. Ezbakhe and Pérez-Foguet [36] introduced a modified multi-criteria decisionmaking technique to incorporate uncertainty of decision environments in the prioritization of alternatives for renewable energy planning. Fitiwi et al. [37] conducted an assessment on renewable energy utilization for the Irish power system under community acceptance policies considering the uncertainty of storage costs. Scott et al. [38] carried out a study on the role of long-term uncertainty in electricity market modelling for renewable energy support policy evaluation. There are other studies that consider uncertainty in different aspects of renewable-related projects, such as load demand uncertainty [39,40]; renewable energy resources uncertainty [41,42]; uncertainties of the inflow of the hydropower plant and the PV power output [43]; wind energy uncertainty [44]; uncertainty in the costs of renewable energy [45]; uncertainties of wind speed, solar radiation intensity, and power load [46]; and uncertainties of renewable energy production and load demand [47].

Since Hybrid Optimization Model for Electric Renewables (HOMER) software has proved applicability and reliability in simulation, analysis, and optimization of renewable power generation systems leading to precise results, it has been utilized in the past few years to explore HRE systems from the techno-economic-environmental perspective. Olatomiwa et al. [48] studied the viability of different configurations of PV, WT, battery, and DG units to be used in a villages in Nigeria using HOMER software. Considering total net present cost (TNPC), levelized cost of electricity (LCOE), and renewable fraction, the combination of PV/DG/battery was identified as the best architecture. In another research conducted in Nigeria, the techno-economic feasibility of a solar-based plant for powering a mobile base transceiver station was analyzed using HOMER. The results suggested a 10-kW PV, a 5.5-kW DG, and 64 units of Trojan battery. It also ended up saving 16.4 tons of $\mathrm{CO}_{2}$ per year in comparison with an autonomous DG plant [49]. Brenna et al. [50] utilized HOMER to assess the different integrations of PV, WT, hydro, DG, battery, and $\mathrm{H}_{2}$ for electrifying a rural area in Ethiopia. Isa et al. [51] proposed an on-grid PV/FC/ battery system for co-supplying electricity and heat to a hospital in Malaysia with a TNPC of $\$ 106,551$, an LCOE of $0.091 \$ / \mathrm{kWh}$, and an emission reduction of 25,873 kg/yr. Singh and Baredar [52] studied the electricity generation potential via an off-grid system consisting of PV, FC, BMG, and battery. Singh et al. [53] employed HOMER to verify the results of optimal sizing of an HRE system which was obtained by swarm-based artificial bee colony and particle swarm optimization. The comparison proved that these three methods had close results as to the sizing of the components. Das et al. [54] explored the techno-economic feasibility of an HRE system using HOMER. The software was employed to compare PV/FC/battery and PV/battery systems with a benchmark of the current DG plant [55]. Khemariya et al. [56] used HOMER to evaluate a PV/FC/battery/electrolyzer system to electrify a village in India. Similarly, HOMER optimized a PV/BMG/DG/battery system considering different peak loads, energy demands, and grid availability [57]. Shahzad et al. [58] designed an integrated PV/BMG/battery system for the irrigation and residential applications in Pakistan. Furthermore, HOMER assessed the techno-economic feasibility of a grid-tied PV/WT/BMG system for electrifying a village in Pakistan [59]. Duman and Guler [60] explored the utilization of an autonomous PV/WT/FC plant to supply electricity for vacation homes in Turkey. HOMER revealed that the displacement of FC 
with batteries would turn the system more cost-effective. Moreover, stand-alone HRE systems were scrutinized using HOMER for a nursing home in Turkey [61]. Apart from those above-mentioned studies, these papers [62-88] also applied HOMER for different purposes, which are helpful in learning about the software and its practicality.

\section{Geographical Specifications}

Mesr village, also locally called Mesr desert, is located in the province of Isfahan and is surrounded by the Great Salt Desert. This remote area is situated at coordinates $34^{\circ} 04^{\prime} \mathrm{N}$ and $54^{\circ} 48^{\prime} \mathrm{E}$, with an altitude of rough $800 \mathrm{~m}$ above the sea level [89]. According to the latest population and housing census conducted in 2016, the village has 41 households with 183 population [90]. By virtue of Mesr's location, many national and international tourists visit this place every year. For this, in addition to the number of personal houses, there are a dozen traditional hotels to accommodate visitors, a healthcare center, a mosque, and a small school. After collecting the information about electricity demand from Isfahan Province Electricity Distribution Company, the daily average electricity load would be approximately $366 \mathrm{kWh}$. The reason why this village consumes this amount of energy is that the number of tourists visiting this touristy rustic area is high in several months of the year. Analyzing the figures and the common electricity-consuming devices, almost $163 \mathrm{kWh} / \mathrm{d}$ of electricity would be used for heating equipment, such as space heating, water heating, and cooking. The rest, which is $203 \mathrm{kWh} / \mathrm{d}$, would be needed by other equipment and appliances, such as air conditioning, fan, bulbs, ironing, television, washing machine, dish washer, refrigerator, etc. Thus, two types of load, electric load and thermal load, are assumed in the proposed models.

\section{Materials and Methods}

HOMER Pro software was developed by the National Renewable Energy Laboratory (NREL) in the USA and has the ability to evaluate HRE systems in both modes of off-grid and on-grid [91]. This software has been extensively utilized because of its suitable accuracy and high speed for optimization [92] and is comparable to meta-heuristic optimization algorithms [53]. Hence, HOMER is applied to serve the purpose of this study.

\subsection{Economic Analysis}

The key economic criterion via which HOMER proposes optimal sizing of HRE systems and prioritizes different configurations is TNPC. The formula to compute TNPC reads as Equation (1) [93].

$$
T N P C=\frac{C_{t o t a l, a n}}{C R F(i, n)}
$$

where $C_{\text {total,an }}$ is designated to the total annualized cost of all equipment to be purchased and installed in the system. $C R F, i$, and $n$, respectively, represent the capital recovery factor, the real yearly discount rate, and the project lifetime. Equation (2) can evaluate the term expressed as the denominator of the above-mentioned relation [94]. HOMER also uses Equation (3) in order to project the real yearly discount rate in which $i^{\prime}$ and $f$ are, respectively, the nominal discount rate and yearly inflation [95].

$$
\begin{gathered}
\operatorname{CRF}(i, n)=\frac{i \times(1+i)^{n}}{(1+i)^{n}-1} \\
i=\frac{i^{\prime}-f}{1+f}
\end{gathered}
$$

The other prominent economic factor is the average price of generating one $\mathrm{kWh}$ of electricity via the designed system and is called $L C O E$, which can be obtained using Equation (4) [51].

$$
L C O E=\frac{C_{\text {total }, a n}}{E_{\text {Prim }, A C}+E_{\text {Prim }, D C}+E_{\text {grid, } E x}}
$$


Here, $E_{\text {Prim }, A C}$ and $E_{\text {Prim,DC }}$ signify the total amount of alternating current (AC) primary load and that of direct current (DC) primary load met by the system within a year. Additionally, $E_{\text {grid,Ex }}$ is the total amount of electricity which is exported to the local/national grid.

It is worth mentioning that another economic factor relatively important to the investors is the scrap value of the apparatus at the end of the project lifetime. This salvage value is directly contingent upon the remaining life of the nominated component holding a linear relation with a corresponding replacement cost. The relations are expressed by Equation (5) [51].

$$
S_{v a l}=C_{r e p} \times \frac{n_{c o m}}{n}
$$

where $C_{\text {rep }}$ refers to the replacement cost of the component when its lifetime, $n_{\text {com }}$, has finished.

The other economic output variable represented by HOMER is operating cost, equating to the annualized value of all costs and revenues except for the initial capital costs. Equation (6) is the relation to project operating cost [96].

$$
C_{o p}=C_{\text {total,an }}-C_{\text {total,ini }} \times \operatorname{CRF}(i, n)
$$

where $C_{\text {total,ini }}$ is designated to the total initial capital costs, which equates to the summation of costs of all equipment in HRE systems.

\subsection{PV Modeling}

Owing to the geographical location of Iran, the country sees approximately 300 sunny days within a year, due to which the total annual solar radiation can reach $2200 \mathrm{kWh}$ [83]. This high potential of solar energy is ready and available to be exploited by PV systems in most parts of the country. To model PV arrays into renewable power generation systems, the output of PV is of high importance and needs to be calculated. HOMER software utilizes Equation (7) to project power output generated by PV [97].

$$
P_{P V}=Y_{P V} \times f_{P V}\left(\frac{\bar{G}_{T}}{\bar{G}_{T, S T C}}\right)\left[1+\alpha_{P}\left(T_{\mathcal{C}}-T_{c, S T C}\right)\right]
$$

where $Y_{P V}$ and $f_{P V}$, respectively, denote the nominal capacity of the PV generator and the derating or reduction factor available on the technical sheet of the product. The latter is applied by HOMER to simulate the real-world operating conditions and then to acquire the most reliable and precise results. $\bar{G}_{T}$ signifies the amount of solar radiation reaching the surface of the PV panels, and $\bar{G}_{T, S T C}$ represents the amount under the standard test environment. $\alpha_{P}$ is designated to show the temperature coefficient of power. $T_{\mathcal{C}}$ and $T_{C, S T C}$ are, respectively, the temperature of the PV cell and that at standard test environment. In order to predict the cell temperature, Equations (8) and (9) are used [97].

$$
\begin{aligned}
& T_{\alpha} G_{T}=\eta_{c} G_{T}+U_{L}\left(T_{\mathcal{c}}-T_{\alpha}\right) \\
& T_{\mathcal{c}}=T_{\alpha}+G_{T}\left(\frac{\tau \alpha}{U_{L}}\right)\left(1-\frac{\eta_{c}}{\tau \alpha}\right)
\end{aligned}
$$

where $\tau$ and $\alpha$ are, respectively, transmittance of PV cover and the solar absorption of the PV panels. $U_{L}$ means the coefficient via which heat is transferred to the surrounding environment, and $T_{\alpha}$ refers to the amount of the ambient temperature. Furthermore, $\eta_{c}$ is the electrical conversion efficiency of the PV panels. HOMER uses Equation (10) in order to measure the cell temperature [85]. It should be noted that, due to the difficulty of calculating the value of $\frac{\tau \alpha}{U_{L}}$, Equation (11) is utilized to substitute the aforementioned 
term with the measurable one. Moreover, the software presumes that the value of $\tau \alpha$ in Equation (9) is 0.9 [96].

$$
\begin{gathered}
T_{c}=T_{\alpha}+G_{T}\left(\frac{T_{c, N O C T}-T_{\alpha, N O C T}}{G_{T, N O C T}}\right)\left(1-\frac{\eta_{\mathcal{c}}}{0.9}\right) \\
\frac{\tau \alpha}{U_{L}}=\frac{T_{c, N O C T}-T_{\alpha, N O C T}}{G_{T, N O C T}}
\end{gathered}
$$

where $T_{c, N O C T}$ is the temperature usually reported by the manufacturers and called the nominal operating cell temperature. This value is obtained under the conditions of no-load operating, $\eta_{c}=0$, an ambient temperature of $20{ }^{\circ} \mathrm{C}, T_{\alpha, N O C T}=20^{\circ} \mathrm{C}$, and an incident radiation of $800 \mathrm{~W} / \mathrm{m}^{2}, G_{T, N O C T}=800 \mathrm{~W} / \mathrm{m}^{2}$.

\subsection{WT Modeling}

To capture the kinetic energy of air in motion, WT units are installed and then turn mechanical energy available in wind into electricity via a rotor with two or more blades coupled to an electric generator [70]. Wind speed varies as the height changes [98]; hence, it is crucial to calculate wind velocity at the hub height. For this, HOMER applies the logarithmic law, as shown in Equation (12), to guess wind speed at the desired elevation [67].

$$
U_{\text {hub }}=U_{\text {anem }} \frac{\ln \left(h_{\text {hub }} / h_{0}\right)}{\ln \left(h_{\text {anem }} / h_{0}\right)}
$$

Here, $U_{h u b}$ and $U_{\text {anem }}$ are wind speed at the hub height, $h_{h u b}$, and wind speed collected at the height of anemometer, $h_{\text {anem }}$, respectively. Furthermore, $h_{0}$ refers to the surface roughness length. Finally, the power produced by the WT generator is estimated using Equation (13) [97].

$$
P_{\mathrm{WT}}=\left(\frac{\rho}{\rho_{0}}\right) P_{\mathrm{WT}, \mathrm{STC}}
$$

where $\rho$ and $\rho_{0}$, respectively, denote the actual density of air and the density of air at standard test conditions with certain pressure and temperature. $P_{W T, S T C}$ is the WT output under standard test conditions which is to be computed by HOMER using the WT's power curve. Two other important values reported on technical sheet of the turbines are cut-off and cut-out wind speeds; no power will be generated if wind speed at the hub height is less than the former or more than the latter [99].

\subsection{Electrolyzer Modeling}

$\mathrm{H}_{2}$ is the most favorable, futuristic energy carrier as it releases virtually zero emissions when being applied. There are no pure $\mathrm{H}_{2}$ molecules available in the surrounding environment. However, it can be obtained via several chemical processes. To this end, water electrolysis is the promising method in which an electrolyzer utilizes electricity to make the decompaction of water into $\mathrm{H}_{2}$ and $\mathrm{O}_{2}$ molecules happen [99]. The essential factor connected with modeling and sizing of an electrolyzer is the $\mathrm{H}_{2}$ production rate which can be projected via Equation (14) [79].

$$
H P R=96 \times \frac{n_{\mathcal{c}} \times I_{\text {Ele }}}{2 F} \times \exp \left(\frac{0.09}{I_{\text {Ele }}}-\frac{75.5}{I_{\text {Ele }}^{2}}\right)
$$

Here, $n_{c}$ denotes the number of cells in series, $F$ is the faraday constant, and $I_{E l e}$ is designated to represent the electrolyzer current. HOMER utilizes Equation (15) to evaluate the required input energy for electrolyzer [100].

$$
E_{E l e}=B_{E l e} \times Q_{N}+A_{E l e} \times Q
$$


where $B_{\text {Ele }}$ and $A_{\text {Ele }}$ are known as curve consumption coefficients. $Q_{N}$ and $Q$ represent the nominal mass flowrate of $\mathrm{H}_{2}$ and the mass flowrate of $\mathrm{H}_{2}$, respectively.

\subsection{FC Modeling}

Renewable-based power generation systems usually suffer from a major weakness derived from the intermittent nature of renewable resources during hours when the sunshine is not available or wind in not blowing. To solve this interrupting issue, one or more types of energy storage or backup systems should be added to the plant. Among which, FC has grasped the attention of system designers especially for rural electrification purposes, as it can be fed by $\mathrm{H}_{2}$ generated via the aid of the excess electricity $[16,88]$. In this study, it is postulated that the type of FC is proton exchange membranes, owing to its benefits such as low-cost maintenance, high energy conversion efficiency, and low operating temperature [101]. To evaluate the output voltage of a FC, Equation (16) can be used [102].

$$
V_{F C}=E-V_{a c t}-V_{\text {ohm }}-V_{\text {conc }}
$$

where the four variables of $E, V_{a c t}, V_{\text {ohm }}, V_{\text {conc }}$ refer to open circuit voltage, activation FC overvoltage, ohmic FC overvoltage, and concentration FC overvoltage, respectively. It is worth mentioning that, in HOMER software, to add a FC to the proposed system, it should be selected from the category of generators. HOMER has provided the option of modifying the characteristics of a generator to simulate and imitate the specifications of a FC [103]. Equation (17) is deployed to predict efficiency of a FC [85].

$$
\eta_{F C}=\frac{\overline{V_{c}} \times n_{c, F C} \times I_{F C}}{Q \times H H V_{h y d}}
$$

Here, $\overline{V_{c}}, n_{c, F C}$, and $I_{F C}$ represent the average voltage of a cell in $\mathrm{FC}$, the total number of cells in FC, and the FC current, respectively. $H H V_{h y d}$ is the gross calorific value existing in $\mathrm{H}_{2}$ which is considered usually between 120 and $142 \mathrm{MJ} / \mathrm{kg}$ [104].

\subsection{BMG Modeling}

Living in the countryside and rural areas usually associates with livestock activities, thus the waste of cattle and other animals is amply available in these particular regions. However, this invaluable resource of energy is mostly being discarded without being properly exploited. In the case study area, most villagers have cattle, including cows, goats, sheep, chickens, camels, mules, and horses, to provide organic products or recreational activities for tourists. Therefore, animal manure is assumed to be the biomass source of the generator simulated and modeled in one of the proposed systems. To turn the energy prevailing in the bio waste into electricity, a gasifier is required for transforming solid bio-residue into a gaseous fuel. Equation (18) is given to project the yearly output electricity of a BMG [53].

$$
E_{b i o}=P_{b i o} \times 8760 \times C U F
$$

where $P_{b i o}$ and CUF signify the rating of BMG and the capacity utilization factor, respectively. Equation (19) evaluates the maximum rating of BMG which is deployed in the proposed system [105].

$$
P_{b i o}^{\max }=\frac{T_{b i o} \times 1000 \times C_{b i o} \times \eta_{b i o}}{365 \times 865 \times O_{b i o}}
$$

Here, $T_{b i o}$ represents the total amount of biomass available to be used in the gasifier. $C_{b i o}$ and $\eta_{b i o}$, respectively, denote the calorific value of the type of biomass to be applied and the efficiency of converting biomass to electricity. $O_{b i o}$ refers to the hours of operating BMG. 


\subsection{Converter Modeling}

One of the indispensable components of an HRE system is the converter in which an inverter and a rectifier are essential parts in order to make the transition from AC to DC, and vice versa, occur [68]. The selection of inverter depends on AC loads and its efficiency can be calculated using Equation (20) [106].

$$
\eta_{\text {inv }}=\frac{P_{\text {inv,out }}}{P_{\text {inv, in }}}
$$

where $P_{i n v, o u t}$ and $P_{i n v, i n}$ are the output power and the input power of inverter, respectively.

\subsection{Thermal Load Controller (TLC) Modeling}

The existence of TLC is of high importance for the heat production system and so it is added to the proposed system in order to transfer the surplus electricity generated via the system to the thermal load. The main benefit brought to the designed system by TLC is improvement of renewable fraction, resulting in fewer emissions [97]. To simulate the role of TLC in the system made by HOMER, it is just required to determine the size and the cost of TLC.

\section{9. $\mathrm{H}_{2}$ Tank Modeling}

To store the produced $\mathrm{H}_{2}$ in excess of the amount required by FC or boiler, a storage should be incorporated in the proposed system. The most vital feature of this component is its ability to endure holding the high-pressure $\mathrm{H}_{2}$ [92]. Equation (21) can calculate the pressure of $\mathrm{H}_{2}$ stored in the tank [107].

$$
P_{H 2, \operatorname{tank}}=\frac{C_{H 2} \times \theta_{H 2} \times T}{V_{H 2}}
$$

Here, $C_{H 2}, \theta_{H 2}$, and $T$ represent the compressibility rate of $\mathrm{H}_{2}$, the gas constant, with a $\mathrm{H}_{2}$ value at $4124.18 \mathrm{Nm} / \mathrm{kg} \cdot \mathrm{K}$, and temperature, respectively. $V_{\mathrm{H} 2}$ is also the specific volume. Similar to TLC, HOMER software just allows the users to set the volume of $\mathrm{H}_{2}$ tank and its price.

\subsection{Boiler Modeling}

In order to add a boiler into the models, the type and price of the fuel, emission factors, and efficiency should be set for the software to simulate the unit. In this regard, efficiency means the fraction of the fuel's energy which is being turned into heat [96].

\section{Technical Characteristics, Cost of Equipment and Assumptions}

To simulate the electricity and heat co-generation system and optimize the size of each component, HOMER needs some technical features and the price of involved equipment. For this, Table 1 lists the technical specifications and costs of all components employed in the system. 
Table 1. Technical specifications and costs of the components.

\begin{tabular}{|c|c|c|c|c|c|c|}
\hline Component & $\begin{array}{c}\text { Model } \\
\text { (Abbreviation) }\end{array}$ & Technical Specifications & Capital Cost & Replacement Cost & $\begin{array}{c}\text { Operation and } \\
\text { Maintenance Cost }\end{array}$ & Ref. for Costs \\
\hline PV & $\begin{array}{l}\text { Fronius Symo 4.5-3-S } \\
\text { (Fron4.5) }\end{array}$ & $\begin{array}{c}\text { Rated capacity: } 4.4 \mathrm{~kW} \\
\text { Lifetime: } 25 \mathrm{yr} \\
\text { Electrical bus: } \mathrm{AC} \\
\text { Derating factor: } 96 \% \\
\text { Temperature coefficient: }-0.41 \% /{ }^{\circ} \mathrm{C} \\
\text { Operating temperature: } 45^{\circ} \mathrm{C} \\
\text { Efficiency at standard test conditions: } 17.3 \% \\
\text { Ground reflectance: } 20 \% \\
\text { Tracking system: no tacking } \\
\text { Panel type: flat plate }\end{array}$ & $2000(\$ / k W)$ & $2000(\$ / k W)$ & 10 (\$/kW.yr) & [97] \\
\hline WT & $\begin{array}{l}\text { Bergey Excel } 6 \\
(\text { XL6) }\end{array}$ & $\begin{array}{c}\text { Rated capacity: } 6 \mathrm{~kW} \\
\text { Lifetime: } 20 \mathrm{yr} \\
\text { Electrical bus: } \mathrm{AC} \\
\text { Hub height: } 30 \mathrm{~m} \\
\text { Rotor diameter: } 6.2 \mathrm{~m} \\
\text { Cut-in wind speed: } 2.5 \mathrm{~m} / \mathrm{s} \\
\text { Cut-out wind speed: none }\end{array}$ & $2000(\$ / \mathrm{kW})$ & $1600(\$ / \mathrm{kW})$ & 50 (\$/\#.yr) & [62] \\
\hline BMG & $\begin{array}{c}\text { Generic Biogas Genset } \\
\text { (Bio) }\end{array}$ & $\begin{array}{c}\text { Size: } 20 \mathrm{~kW} \\
\text { Lifetime: } 20,000 \mathrm{~h} \\
\text { Electrical bus: AC } \\
\text { Fuel type: animal manure } \\
\text { LHV = } 19 \mathrm{MJ} / \mathrm{kg} \\
\text { Gasification ratio: } 0.047 \mathrm{~kg} / \mathrm{kg} \\
\text { Density of biogas: } 1.15 \mathrm{~kg} / \mathrm{m}^{3} \\
\text { Carbon content: } 44 \% \\
\text { Daily available biomass: } 2000 \mathrm{~kg} \\
\text { Biogas fuel price: } 0 \$ / \mathrm{kg}\end{array}$ & $2300(\$ / \mathrm{kW})$ & $1500(\$ / \mathrm{kW})$ & 0.01 (\$/op.h) & [53] \\
\hline
\end{tabular}


Table 1. Cont.

\begin{tabular}{|c|c|c|c|c|c|c|}
\hline Component & $\begin{array}{c}\text { Model } \\
\text { (Abbreviation) }\end{array}$ & Technical Specifications & Capital Cost & Replacement Cost & $\begin{array}{c}\text { Operation and } \\
\text { Maintenance Cost }\end{array}$ & Ref. for Costs \\
\hline $\mathrm{FC}$ & $\begin{array}{l}\text { Generic Fuel Cell } \\
\text { (FC) }\end{array}$ & $\begin{array}{c}\text { Size: } 20 \mathrm{~kW} \\
\text { Lifetime: } 50,000 \mathrm{~h} \\
\text { Electrical bus: DC } \\
\text { Heat recover ratio: } 60 \% \\
\text { Minimum runtime: } 20 \mathrm{~min} \\
\text { Fuel type: stored hydrogen } \\
\text { LHV = } 120 \mathrm{MJ} / \mathrm{kg} \\
\text { Carbon content: } 0 \\
\text { Stored hydrogen price: } 0 \$ / \mathrm{kg}\end{array}$ & $2000(\$ / k W)$ & $1860(\$ / \mathrm{kW})$ & 0.01 (\$/op.h) & [92] \\
\hline TLC & $\begin{array}{l}\text { Generic thermal load } \\
\text { controller (TLC) }\end{array}$ & $\begin{array}{c}\text { Size: } 100 \mathrm{~kW} \\
\text { Lifetime: } 20 \mathrm{yr} \\
\text { Electrical bus: DC and AC }\end{array}$ & $54(\$ / k W)$ & $54(\$ / k W)$ & $0(\$ / \mathrm{kW})$ & [97] \\
\hline Boiler & Generic boiler & $\begin{array}{c}\text { Efficiency: } 85 \% \\
\text { Fuel type 1: stored hydrogen } \\
\text { LHV= } 120 \mathrm{MJ} / \mathrm{kg} \\
\text { Carbon content: } 0 \\
\text { Stored hydrogen price: } 0 \$ / \mathrm{kg} \\
\text { Fuel type 2: natural gas } \\
\text { LHV }=45 \mathrm{MJ} / \mathrm{kg} \\
\text { Density: } 0.79 \mathrm{~kg} / \mathrm{m}^{3} \\
\text { Carbon content: } 67 \% \\
\text { Natural gas price: } 0.3 \$ / \mathrm{m}^{3}\end{array}$ & - & - & - & - \\
\hline Converter & $\begin{array}{c}\text { Leonics S-219Cp } 5 \mathrm{~kW} \\
\text { (Leon5) }\end{array}$ & $\begin{array}{c}\text { Lifetime: } 10 \mathrm{yr} \\
\text { Rectifier efficiency: } 94 \% \\
\text { Rectifier relative capacity: } 80 \% \\
\text { Inverter efficiency: } 96 \%\end{array}$ & $550(\$ / \mathrm{kW})$ & $550(\$ / k W)$ & $10(\$ / \mathrm{kW} / \mathrm{yr})$ & [108] \\
\hline Electrolyzer & Generic Electrolyzer & $\begin{array}{l}\text { Size: specified in model } \\
\text { Lifetime: } 15 \mathrm{yr} \\
\text { Electrical bus: DC } \\
\text { Efficiency: } 85 \%\end{array}$ & $2000(\$ / k W)$ & $2000(\$ / k W)$ & $50(\$ / \mathrm{kW} / \mathrm{yr})$ & [93] \\
\hline $\mathrm{H}_{2}$ Tank & $\begin{array}{c}\text { Generic hydrogen tank } \\
\text { (H2Tank) }\end{array}$ & Initial tank level: 0 & $600(\$ / \mathrm{kg})$ & $600(\$ / \mathrm{kg})$ & $10(\$ / y r)$ & [109] \\
\hline
\end{tabular}


A nominal discount rate with a mean value of $17.5 \%$ and inflation with that of $18 \%$ are deemed the benchmark case for further judgment. Then, to assess the impact of economic uncertainty on optimal sizing, the nominal discount rate and inflation are postulated to fluctuate in the range of $15-20 \%$ and $10-26 \%$, respectively, based on the figures of a period of 20 years [23]. This consideration seems to be essential in order to obtain the most prospective results bounded by the worst-case and best-case scenarios. As mentioned, for the case when the boiler consumes NG, it is assumed that the price of fuel would equal $\$ 0.3 / \mathrm{m}^{3}$ [92]. Finally, it is presumed that the project lifespan would be 25 years.

As discussed, Mesr village is a touristy area attracting many visitors throughout the year. Therefore, electrical demand is relatively high compared to its number of residents. According to the load profile reported by Isfahan Province Electricity Distribution Company, electricity consumption for purposes other than heating possesses an average of $203.35 \mathrm{kWh} / \mathrm{d}$ with a peak of $27.44 \mathrm{~kW}$. On the other side, daily average electricity requirement for thermal usage would be $163.23 \mathrm{kWh}$ with a peak of $42.91 \mathrm{~kW}$. It should be clarified that the figures associated with the electrical load revealed that electricity served for heating applications, such as space heating, water heating, and cooking, would be almost $80 \%$ of that served for other usages, such as lighting, cooling, kitchen appliances, etc. Figures 3 and 4 depict these two profiles on an hourly, daily, and monthly basis.
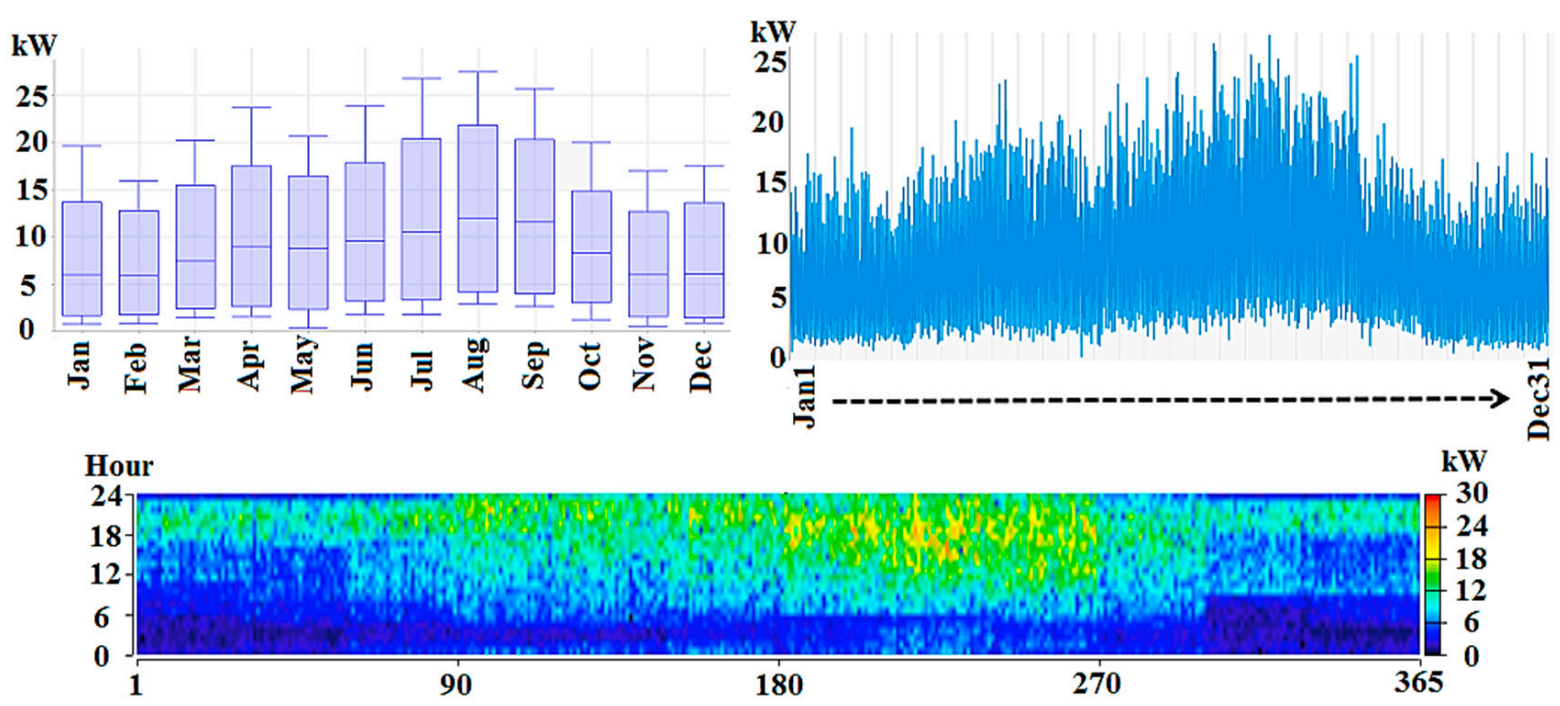

Figure 3. The hourly, daily and monthly profile of electric load.
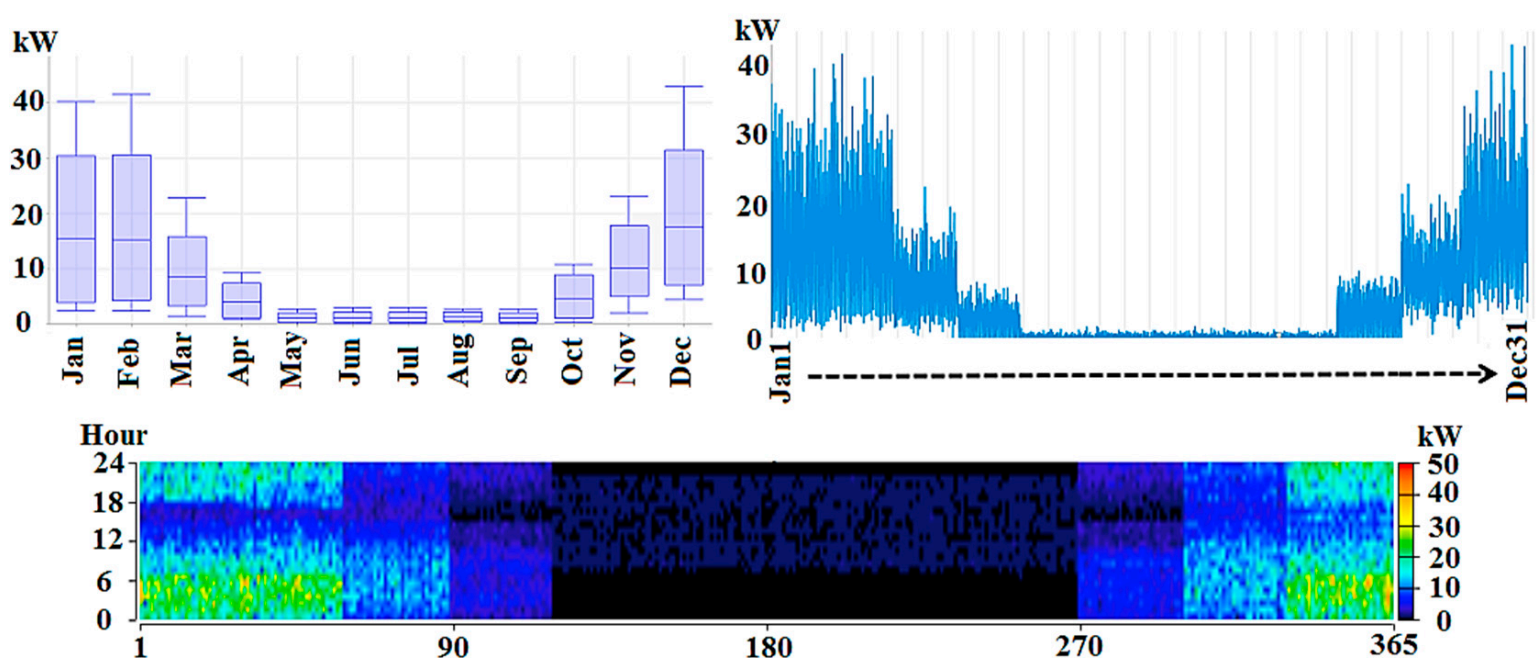

Figure 4. The hourly, daily and monthly profile of thermal load. 
In this study, the three following configurations are analyzed as illustrated in Figures 5-7:

(I) $\mathrm{PV} / \mathrm{WT} /$ electrolyzer $/ \mathrm{H}_{2}$-based $\mathrm{FC} / \mathrm{H}_{2}$-based boiler

(II) $\mathrm{PV} / \mathrm{WT} /$ electrolyzer $/ \mathrm{H}_{2}$-based $\mathrm{FC} / \mathrm{NG}$-based boiler

(III) $\mathrm{PV} / \mathrm{WT} / \mathrm{BMG} /$ electrolyzer $/ \mathrm{H}_{2}$-based boiler

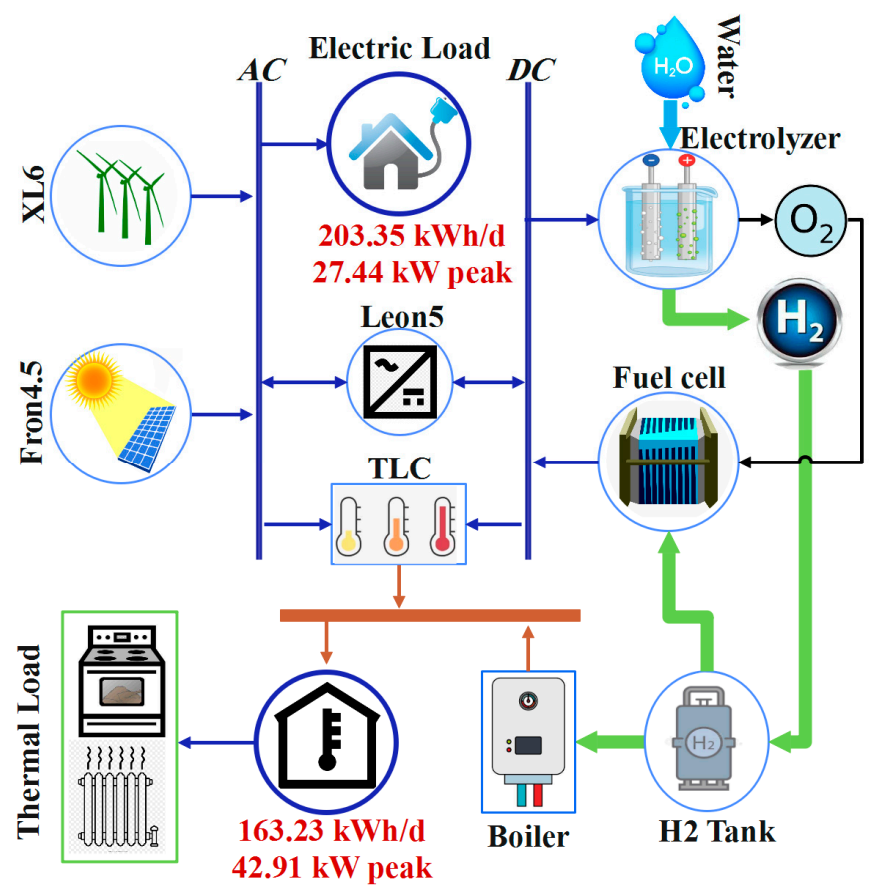

Figure 5. Schematic of the first model simulated by HOMER.

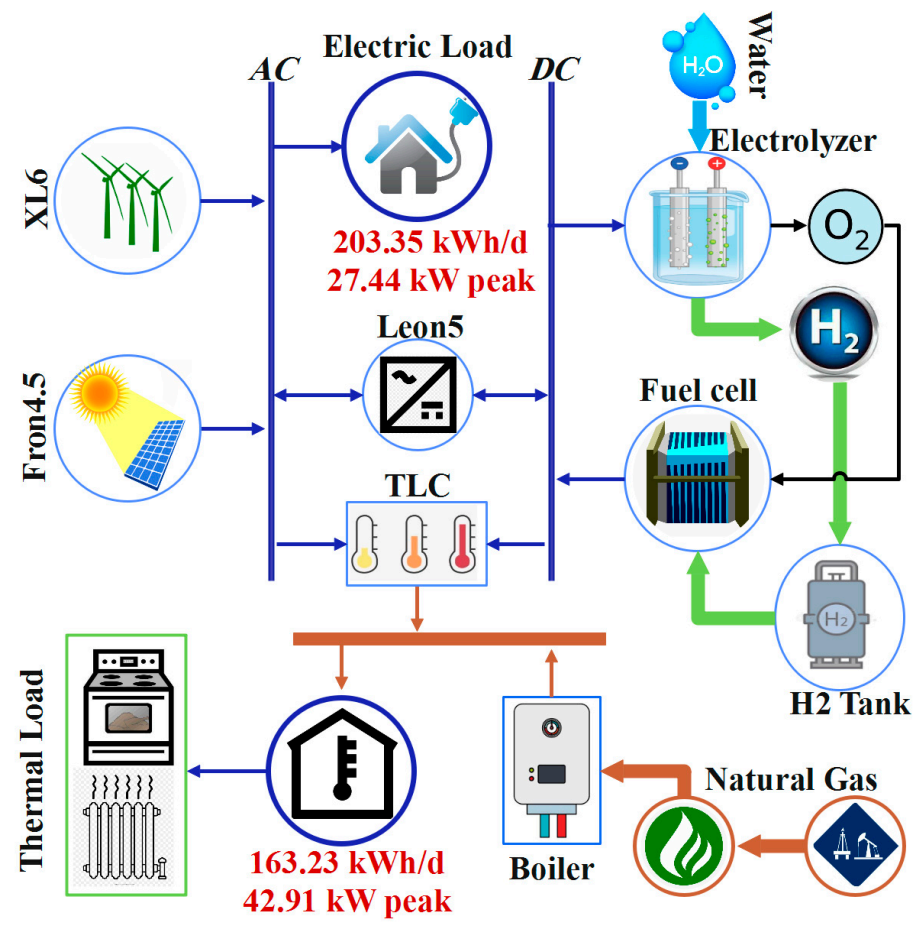

Figure 6. Schematic of the second model simulated by HOMER. 


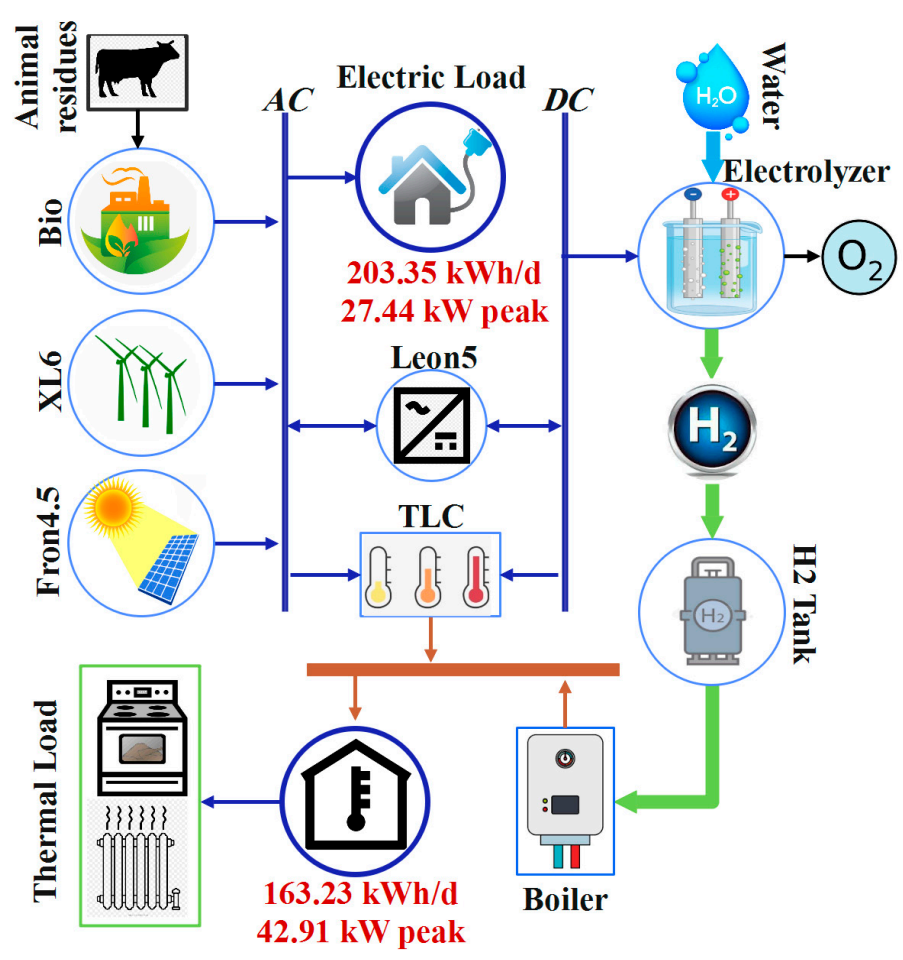

Figure 7. Schematic of the third model simulated by HOMER.

\section{Analysis}

\subsection{The Benchmark Case ( $i=17.5 \%$ and $f=18 \%$ )}

In the first model simulated and analyzed by HOMER, it was assumed that FC and boiler backups consume renewable $\mathrm{H}_{2}$ yielded by electrolyzer. In the second model boiler, it would use NG as fuel and just FC would consume renewable $\mathrm{H}_{2}$. In the third model, BMG would be utilized instead of FC and just boiler would run on renewable $\mathrm{H}_{2}$. LCOE and TNPC of the first model in its benchmark case would equate to $0.33 \$ / \mathrm{kWh}$ and $\$ 647,708$, respectively, which are higher than those of the two other configurations. However, at the end of the project lifetime, the salvage value of components utilized in the first model would be greater than that of the other models. Table 2 provides the results of optimal sizing and economic assessment of the models.

Table 2. Optimization results of simulating the models.

\begin{tabular}{|c|c|c|c|c|c|c|c|c|c|c|c|}
\hline Model & $\begin{array}{c}\mathrm{PV} \\
(\mathrm{kW})\end{array}$ & $\begin{array}{l}\text { WT } \\
\text { (\#) }\end{array}$ & $\begin{array}{c}\mathrm{FC} \\
(\mathrm{kW})\end{array}$ & $\begin{array}{l}\text { BMG } \\
(\mathrm{kW})\end{array}$ & $\begin{array}{c}\text { Electrolyzer } \\
(\mathrm{kW})\end{array}$ & $\begin{array}{l}\text { TLC } \\
(\mathrm{kW})\end{array}$ & $\begin{array}{c}\mathrm{H}_{2} \text { Tank } \\
(\mathrm{kg})\end{array}$ & $\begin{array}{c}\text { Converter } \\
(\mathbf{k W})\end{array}$ & $\begin{array}{c}\text { TNPC } \\
(\$)\end{array}$ & $\begin{array}{l}\text { LCOE } \\
(\$)\end{array}$ & $\underset{\text { (\$) }}{\text { Salvage Value }}$ \\
\hline No. 1 & 33.8 & 14 & $20 *$ & - & $40 *$ & $100 *$ & $10 *$ & 48.7 & 647,708 & 0.33 & $-177,219$ \\
\hline No. 2 & 28.4 & 9 & $20 *$ & - & $20 *$ & $100 *$ & $10 *$ & 28.8 & 548,906 & 0.248 & $-139,048$ \\
\hline No. 3 & 43 & 8 & - & $20 *$ & $30 *$ & 100 * & 10 * & 37.1 & 488,878 & 0.313 & $-131,344$ \\
\hline
\end{tabular}

The numbers with $*$ mean that HOMER does not optimize them. So, they should be determined by the user of the software. For this, the size of electrolyzer is set $20 \mathrm{~kW}$ in the second model in which just FC consumes $\mathrm{H}_{2}$, while in the other models is 30 and $40 \mathrm{~kW}$.

In relation to the technical results of these systems under the benchmark case, Table 3 demonstrates total electricity and thermal energy generation along with other findings. With regard to the unmet electric load, the first and second proposed systems showed promising figures, which would breed high reliability. Even though the third system had less TNPC compared to the two other models, its unmet electric load revealed that it could not be relied upon. Comparing the first and second models in terms of their TNPC, the latter would be more cost-efficient. Irrespective of TNPC, the second model would roughly emit 11.5 tons/year of $\mathrm{CO}_{2}$ which is its main disadvantage, as it is not being eco-friendly. Based on the findings represented in Table 3 , the first model would perfectly meet all electric and 
thermal energy demands, and would also be the most environmentally-friendly one. Thus, in the following sub-section, this model is analyzed considering economic uncertainty.

Table 3. Technical results of analyzing the models.

\begin{tabular}{|c|c|c|c|}
\hline & Model No. 1 & Model No. 2 & Model No. 3 \\
\hline Total electricity production (kWh/yr) & 241,422 & 180,162 & 181,722 \\
\hline The share of PV $(\%)$ & 25.6 & 29 & 40.9 \\
\hline The share of WT (\%) & 65.9 & 56.7 & 50 \\
\hline The share of FC (\%) & 8.5 & 14.3 & - \\
\hline The share of BMG $(\%)$ & - & - & 9.1 \\
\hline Excess electricity (kWh/yr) & 30,773 & 27,869 & 15,719 \\
\hline Unmet electric load (\%) & 0.051 & 0.065 & 20.5 \\
\hline Renewable fraction & 43.9 & 41.7 & 53.3 \\
\hline Total thermal energy production $(\mathrm{kWh} / \mathrm{yr})$ & 85,234 & 80,134 & 71,153 \\
\hline The share of boiler $(\%)$ & 63.9 & 65.2 & 77.9 \\
\hline The share of excess electricity (\%) & 36.1 & 34.8 & 22.1 \\
\hline Excess thermal energy $(\mathrm{kWh} / \mathrm{yr})$ & 25,655 & 20,556 & 11,574 \\
\hline $\mathrm{H}_{2}$ consumption by $\mathrm{FC}(\mathrm{kg} / \mathrm{yr})$ & 618 & 771 & - \\
\hline Capacity factor of FC $(\%)$ & 11.7 & 14.7 & - \\
\hline Biomass consumption by BMG (tonnes/yr) & - & - & 730 \\
\hline Capacity factor of BMG $(\%)$ & - & - & 9.5 \\
\hline Total renewable production divided by load (\%) & 109 & 105 & 114 \\
\hline Capacity factor of PV $(\%)$ & 20.9 & 21 & 19.7 \\
\hline Capacity factor of WT (\%) & 21.6 & 21.6 & 21.6 \\
\hline $\mathrm{H}_{2}$ consumption by boiler $(\mathrm{kg} / \mathrm{yr})$ & 1922 & - & 1956 \\
\hline NG consumption by boiler $\left(\mathrm{m}^{3} / \mathrm{yr}\right)$ & - & 6905 & - \\
\hline Total $\mathrm{H}_{2}$ generation by electrolyzer $(\mathrm{kg} / \mathrm{yr})$ & 2759 & 1575 & 2167 \\
\hline Capacity factor of electrolyzer $(\%)$ & 36.5 & 41.7 & 38.3 \\
\hline $\mathrm{CO}_{2}$ emission $(\mathrm{kg} / \mathrm{yr})$ & 0 & 11,535 & 1175 \\
\hline
\end{tabular}

\subsection{Analysis of the First Model under Economic Uncertainty}

As mentioned, predicting the future value of money in underdeveloped countries may be onerous due to the high fluctuations in the discount rate and inflation. Hence, to obtain the most likely results as to the economics of $\mathrm{PV} / \mathrm{WT} /$ electrolyzer $/ \mathrm{H}_{2}$-based $\mathrm{FC} / \mathrm{H}_{2}$-based boiler system, the least and the highest prospective amounts of these rates were incorporated into the projections. To this end, the nominal discount rate and inflation were considered to vary in the range of $15-20 \%$ and $10-26 \%$, respectively, based on the 20-year average from mid-2000 to mid-2020.

The results proved that, if the nominal discount rate, $i$, rose, and the inflation rate, $f$, declined, then LCOE would increase. For instance, when $i=15 \%$ and $f=26 \%$, the amount of LCOE would equate to $0.102 \$ / \mathrm{kWh}$, which is less than one-third of the benchmark value $=0.33 \$ / \mathrm{kWh}$. On the other side, when $i=20 \%$ and $f=10 \%$, LCOE would augment significantly over twofold of the benchmark value to $0.662 \$ / \mathrm{kWh}$. Figure 8 depicts the surface plot of the variations in TNPC, considering the fluctuations of these two rates.

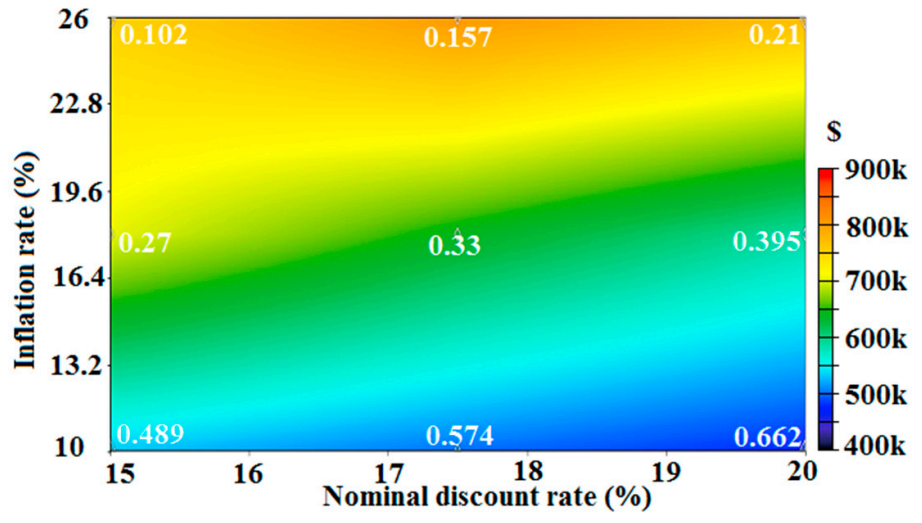

Figure 8. Changes of TNPC considering the fluctuations of the nominal discount rate and inflation (numbers inside the surface plot refer to LCOE). 
Figure 9 demonstrates the surface plot concerned with annual electric production as a consequence of the variations in the rates. It can be inferred that, for the case when $i$ lowered and $f$ grew, the electric production would increase and LCOE would diminish. Furthermore, Figure 10 provides the status of annual thermal energy generation considering different values of $i$ and $f$.

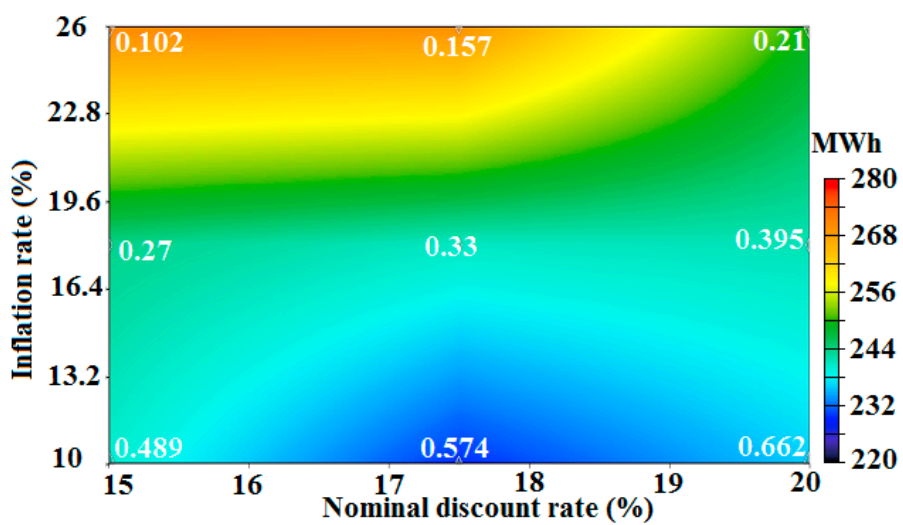

Figure 9. Changes of annual electric production considering the fluctuations of the nominal discount rate and inflation (Numbers inside the surface plot refer to LCOE).

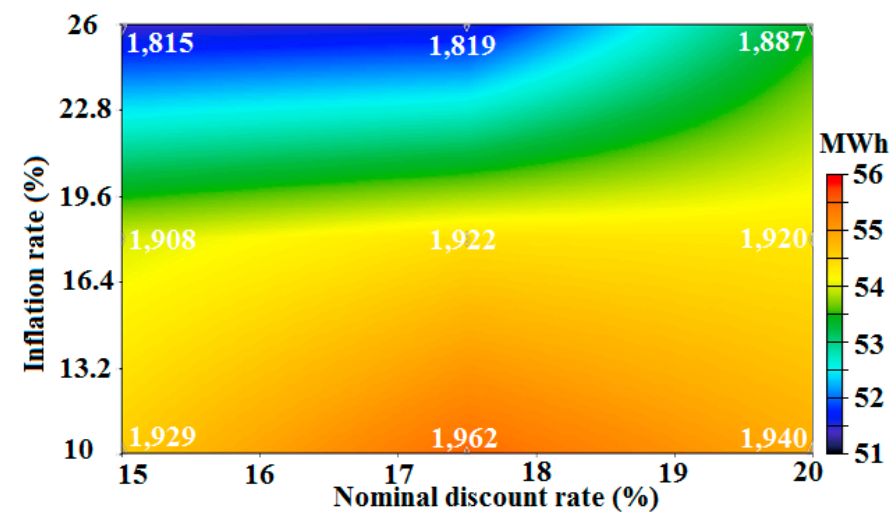

Figure 10. Changes of annual thermal energy generation considering the fluctuations of the nominal discount rate and inflation (numbers inside the surface plot refer to the amount of $\mathrm{H}_{2}$ consumed by boiler).

Finally, Figures 11-13, respectively, show electricity generation via FC, via PV, and via WT units, when $i$ and $f$ vary.

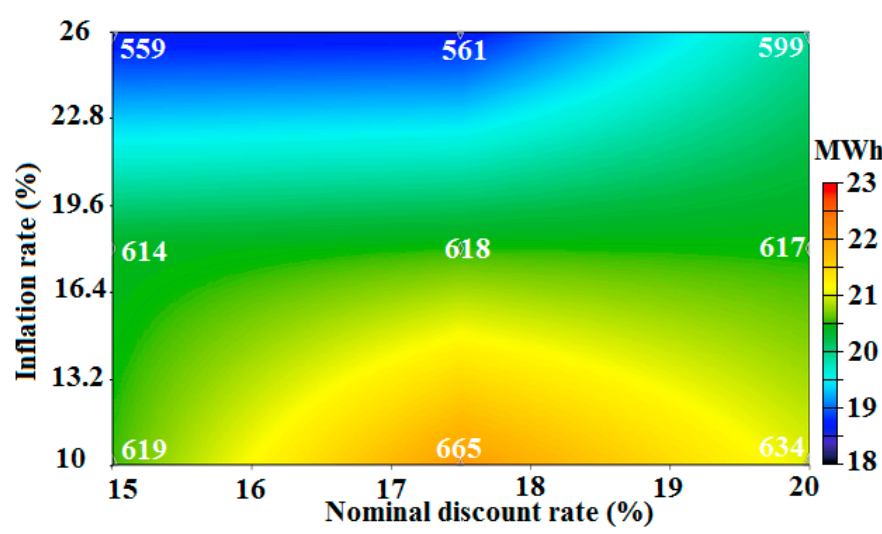

Figure 11. Changes of electricity generation via FC considering the fluctuations of the nominal discount rate and inflation (numbers inside the surface plot refer to the amount of $\mathrm{H}_{2}$ consumed by $\mathrm{FC}$ ). 


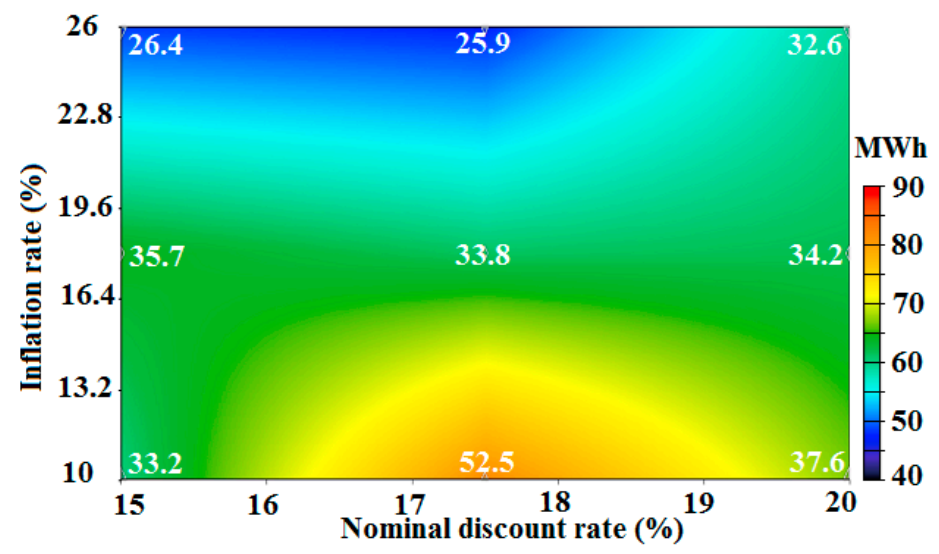

Figure 12. Changes of electricity generation via PV considering the fluctuations of the nominal discount rate and inflation (numbers inside the surface plot refer to the optimal size of PV).

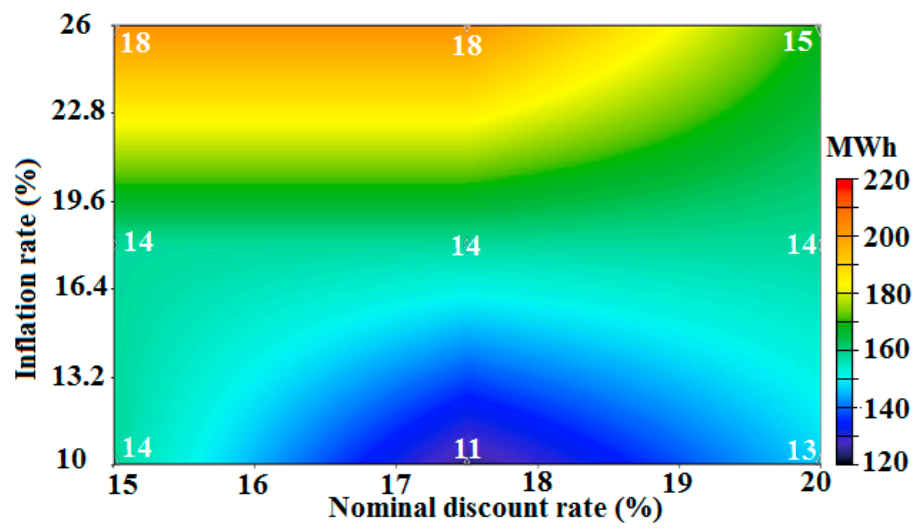

Figure 13. Changes of electricity generation via WT units considering the fluctuations of the nominal discount rate and inflation (numbers inside the surface plot refer to the optimal number of the wind turbines).

In Figure 13, the central part of the chart shows the values related to the benchmark case.

\section{Discussion and Suggestions for Implementation}

One of the most vital criteria that would hinder the exploitation of renewable energies in underdeveloped nations is economic uncertainty. Owing to some unforeseeable factors impinging upon the value of currency in these countries, speculation on economics of projects seems to be difficult. For example, Iran has experienced many ups and downs in its currency value due to lifting and imposing international sanctions. However, this issue can be dealt with via considering the fluctuations in the discount rate and inflation. To this end, in this study, the mean values of these rates were first incorporated into the calculations to set a benchmark case. Then, the most possible range of changes for these two rates were taken into account.

As the results of economic uncertainty analysis indicated, LCOE of the nominated system, $\mathrm{PV} / \mathrm{WT}$ /electrolyzer $/ \mathrm{H}_{2}$-based $\mathrm{FC} / \mathrm{H}_{2}$-based boiler, would not be cost-competitive to conventional methods of electricity generation under the majority of likely values of the discount rate and inflation. Here, the role of the government and its underwriting policies are extremely decisive in the implementation of the proposed system in the nominated remote area. To achieve energy security, to decarbonize and decentralize energy sector, to meet the Paris Agreement emission targets, and to sustain the environment, governments should underpin such schemes by the following.

(I) Furnishing the investors or private companies with zero percent or low-rate loans. 
(II) Introducing carbon tax to encourage the generation and use of renewable electricity.

(III) Setting strict rules and regulations against carbon-intensive means of generating electricity.

(IV) Developing the concept of green tourism to attract as many national and international visitors as possible. The corresponding revenues can cover a substantial proportion of the project's costs.

(V) Subsidizing the price of renewable electricity for residents (can be achieved from the resource of funding allocated to operating and maintaining the transmission and distribution network as it would no longer be needed).

(VI) Lifting tariffs on importing equipment such as PV, WT, electrolyzer, FC, etc.

It is less doubtful that these carbon neutral remote power generation systems will be eventually valued in the marketplace, owing to their differentiated and distinguished quality of energy, if serious constraints in the energy market are imposed on carbon production.

\section{Conclusions}

In the first part of analysis, three models for co-supplying a touristy village with electricity and heat were proposed and analyzed in terms of technical, economic, environmental, and reliability aspects under the conditions of the benchmark case, $i=17.5 \%$ and $f=18 \%$, taken from the average value of a 20 -year period. The following results were obtained:

- The first model, the PV/WT/electrolyzer/ $\mathrm{H}_{2}$-based FC/ $\mathrm{H}_{2}$-based boiler, had the highest TNPC $(\$ 647,708)$, the lowest unmet electric load, and the highest reliability without any detrimental impact on the environment.

- The second model, the PV/WT/electrolyzer/ $\mathrm{H}_{2}$-based FC/NG-based boiler, possessed the second least TNPC $(\$ 548,906)$, and it could meet almost all electric demand. Whereas, utilizing it would end up releasing some 11.5 tons of $\mathrm{CO}_{2}$ per year. This carbon footprint constitutes a challenging negative point for the second model which may strongly inhibit all the attempts to accomplish the Paris Agreement targets.

- The techno-economic analysis of the third model, the PV/WT/BMG/electrolyzer/ $\mathrm{H}_{2}$ based boiler, showed that it would not be reliable, as $20.5 \%$ of total electric load could not be met via this system. However, its TNPC, $\$ 488,878$, was the least amongst the three analyzed configurations.

In the second part of the paper, the fluctuations in $i$ and $f$ were in accordance with the 20 -year average from mid-2000 to mid-2020, respectively, between $15-20 \%$ and $10-26 \%$. The results of technical and economic assessment of the first model under economic uncertainty and comparison with the related values of the benchmark case are as follows:

- The amount of LCOE would vary from $0.102 \$ / \mathrm{kWh}$ to $0.662 \$ / \mathrm{kWh}$, meaning LCOE could be between one-third of the benchmark value and two-fold that (LCOE for the benchmark case $=0.33 \$ / \mathrm{kWh})$. Additionally, TNPC would fluctuate between $\$ 478,704$ and $\$ 814,905$ from $26 \%$ less than the benchmark value up to $26 \%$ more than that (TNPC for the benchmark case $=\$ 647,708$ ).

- $\quad$ The optimal size of PV and the number of WT units would change from 25.9 to $52.5 \mathrm{~kW}$ and from 11 to 18, respectively. Comparing with the benchmark case (PV size $=33.8 \mathrm{~kW}$ and number of WT units $=14$ ), the PV size could vary from an amount of $23 \%$ less than the benchmark case up to $55 \%$ more than that, and corresponding figures for WT would be $21 \%$ and $29 \%$, respectively.

- The amount of renewable $\mathrm{H}_{2}$ consumed by boiler and FC would be in the ranges of $1815-1962 \mathrm{~kg}$ and 559-665 kg, respectively. When comparing with the benchmark $\left(\mathrm{H}_{2}\right.$ consumption in boiler $=1922 \mathrm{~kg}$ and that in $\mathrm{FC}=618$ ), the former would fluctuate from an amount of $6 \%$ less than the benchmark value up to an amount of $2 \%$ more than that, and related numbers for FC would be $10 \%$ and $8 \%$, respectively. 


\section{Future Research Direction}

The authors stimulate researchers to conduct a study for ascertaining the political, social, and geographical barriers to the development of such programs in developing countries and then introducing firm and applicable blueprints for eliminating these obstacles.

Author Contributions: M.R.: Conceptualization, Data curation, Formal analysis, Investigation, Methodology, Resources, Software, Validation, Visualization, Writing-original draft, Writingreview \& editing; U.D.: Conceptualization, Formal analysis, Investigation, Resources, Validation, Visualization; B.K.D.: Conceptualization, Formal analysis, Investigation, Resources, Validation, Visualization; O.N.: Funding acquisition, Project administration, Validation; P.F.B.: Conceptualization, Formal analysis, Investigation, Software, Validation, Visualization; M.A.M.: Conceptualization, Data curation, Formal analysis, Investigation, Methodology, Resources, Software, Supervision, Validation, Visualization, Writing — original draft, Writing—review \& editing. All authors have read and agreed to the published version of the manuscript.

Funding: This project was supported by Researchers Supporting Project number (RSP-2021/257), King Saud University, Riyadh, Saudi Arabia.

Institutional Review Board Statement: Not applicable.

Informed Consent Statement: Not applicable.

Data Availability Statement: Authors acknowledge that data pertinent to this study will be provided upon request.

Conflicts of Interest: The authors declare no conflict of interest.

\section{Nomenclature}

\begin{tabular}{|c|c|}
\hline $\mathrm{AC}$ & Alternating Current \\
\hline$A_{E l e}$ and $B_{E l e}$ & Curve consumption coefficients $(\mathrm{kW} / \mathrm{kg} / \mathrm{h})$ of electrolyzer \\
\hline BMG & Biomass generator \\
\hline$C_{\text {bio }}$ & Biomass's calorific value \\
\hline $\mathrm{C}_{\mathrm{H} 2}$ & Compressibility rate of hydrogen \\
\hline$C_{o p}$ & Operating cost (\$) \\
\hline$C_{\text {rep }}$ & Replacement cost (\$) \\
\hline$C R F$ & Capacity rate factor \\
\hline$C_{\text {total,an }}$ & Total annualized cost $(\$)$ \\
\hline$C_{\text {total,ini }}$ & Total initial capital cost $(\$)$ \\
\hline CUF & Capacity utilization factor \\
\hline DC & Direct Current \\
\hline DG & Diesel generator \\
\hline$E$ & Open circuit voltage $(\mathrm{v})$ \\
\hline$E_{b i o}$ & Annual output electricity of a biomass gasifier $(\mathrm{kW})$ \\
\hline$E_{\text {Ele }}$ & Required electricity by the electrolyzer $(\mathrm{kW})$ \\
\hline$E_{\text {grid,Ex }}$ & Electricity sold to the grid $(\mathrm{kWh} / \mathrm{yr})$ \\
\hline$E_{\text {Prim }, A C}$ & AC primary load served $(\mathrm{kWh} / \mathrm{yr})$ \\
\hline$E_{\text {Prim }, D C}$ & DC primary load served (kWh/yr) \\
\hline$f$ & Annual inflation rate $(\%)$ \\
\hline$F$ & Faraday constant \\
\hline FC & Fuel cell \\
\hline$f_{P V}$ & Degradation factor (\%) of PV \\
\hline $\bar{G}_{T}$ & Solar radiation $\left(\mathrm{W} / \mathrm{m}^{2}\right)$ \\
\hline$G_{T, N O C T}$ & Amount of solar radiation at which NOCT is defined which equals $800 \mathrm{~W} / \mathrm{m}^{2}$ \\
\hline $\bar{G}_{T, S T C}$ & Standard radiation $\left(\mathrm{W} / \mathrm{m}^{2}\right)$ \\
\hline$h_{0}$ & Surface roughness length $(\mathrm{m})$ \\
\hline $\mathrm{H}_{2}$ & Hydrogen \\
\hline$h_{\text {anem }}$ & Anemometer height (m) \\
\hline$h_{h u b}$ & Hub height (m) \\
\hline$H P R$ & Hydrogen production rate \\
\hline
\end{tabular}




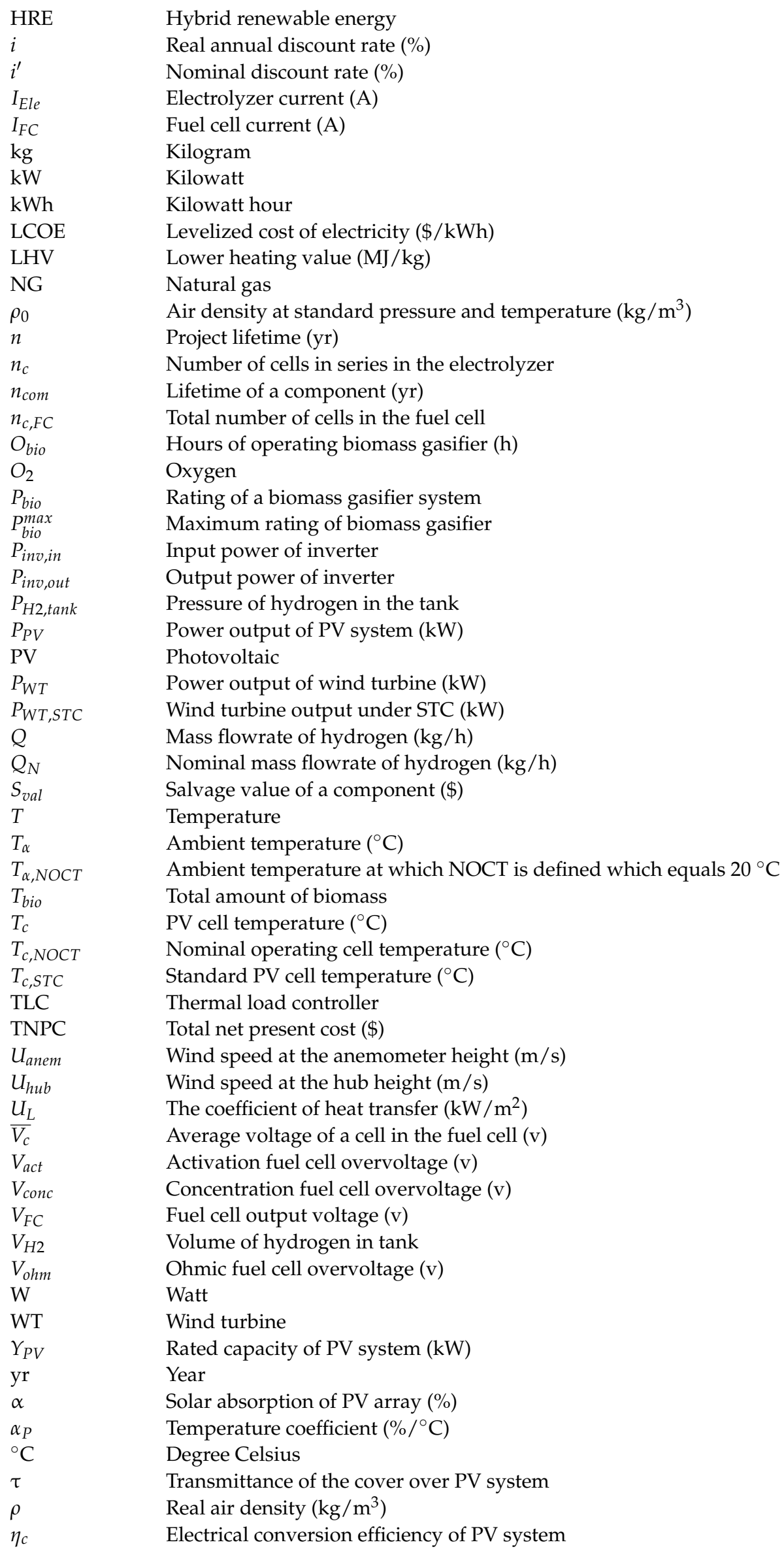




$\begin{array}{ll}\eta_{b i o} & \text { Biomass to electricity conversion efficiency } \\ \eta_{F C} & \text { Fuel cell efficiency } \\ \eta_{i n v} & \text { Inverter efficiency } \\ \theta_{H 2} & \text { Hydrogen gas constant }(4124.18 \mathrm{Nm} / \mathrm{kg} . \mathrm{K})\end{array}$

\section{References}

1. Al-Ghussain, L.; Ahmad, A.D.; Abubaker, A.M.; Mohamed, M.A. An integrated photovoltaic/wind/biomass and hybrid energy storage systems towards $100 \%$ renewable energy microgrids in university campuses. Sustain. Energy Technol. Assess. 2021, $46,101273$.

2. Mostafaeipour, A.; Rezayat, H.; Rezaei, M. A thorough investigation of solar-powered hydrogen potential and accurate location planning for big cities: A case study. Int. J. Hydrogen Energy 2020, 45, 31599-31611. [CrossRef]

3. Mohamed, M.A.; Abdullah, H.M.; El-Meligy, M.A.; Sharaf, M.; Soliman, A.T.; Hajjiah, A. A novel fuzzy cloud stochastic framework for energy management of renewable microgrids based on maximum deployment of electric vehicles. Int. J. Electr. Power Energy Syst. 2021, 129, 106845. [CrossRef]

4. Rezaei, M.; Mostafaeipour, A.; Jafari, N.; Naghdi-Khozani, N.; Moftakharzadeh, A. Wind and solar energy utilization for seawater desalination and hydrogen production in the coastal areas of southern Iran. J. Eng. Des. Technol. 2020, 18, 1951-1969. [CrossRef]

5. Rezaei, M.; Khalilpour, K.R.; Mohamed, M.A. Co-production of electricity and hydrogen from wind: A comprehensive scenariobased techno-economic analysis. Int. J. Hydrogen Energy 2021, 46, 18242-18256. [CrossRef]

6. Samy, M.M.; Mosaad, M.I.; Barakat, S. Optimal economic study of hybrid PV-wind-fuel cell system integrated to unreliable electric utility using hybrid search optimization technique. Int. J. Hydrogen Energy 2020, 46, 11217-11231. [CrossRef]

7. Wang, S.; Wang, S.; Liu, J. Life-cycle green-house gas emissions of onshore and offshore wind turbines. J. Clean. Prod. 2019, 210, 804-810. [CrossRef]

8. Sedaghat, A.; Mostafaeipour, A.; Rezaei, M.; Jahangiri, M.; Mehrabi, A. A new semi-empirical wind turbine capacity factor for maximizing annual electricity and Hydrogen production. Int. J. Hydrogen Energy 2020, 45, 15888-15903. [CrossRef]

9. Al-Ghussain, L.; Ahmad, A.D.; Abubaker, A.M.; Abujubbeh, M.; Almalaq, A.; Mohamed, M.A. A Demand-Supply MatchingBased Approach for Mapping Renewable Resources Towards 100\% Renewable Grids in 2050. IEEE Access 2021, 9, 58634-58651. [CrossRef]

10. Alshammari, N.; Asumadu, J. Optimum unit sizing of hybrid renewable energy system utilizing harmony search, Jaya and particle swarm optimization algorithms. Sustain. Cities Soc. 2020, 60, 102255. [CrossRef]

11. Mohamed, M.A.; Almalaq, A.; Abdullah, H.M.; Alnowibet, K.A.; Alrasheedi, A.F.; Zaindin, M.S.A. A Distributed Stochastic Energy Management Framework Based-Fuzzy-PDMM for Smart Grids Considering Wind Park and Energy Storage Systems. IEEE Access 2021, 9, 46674-46685. [CrossRef]

12. Abbassi, A.; Dami, M.A.; Jemli, M. A statistical approach for hybrid energy storage system sizing based on capacity distributions in an autonomous PV/Wind power generation system. Renew. Energy 2017, 103, 81-93. [CrossRef]

13. Guo, S.; He, Y.; Pei, H.; Wu, S. The multi-objective capacity optimization of wind-photovoltaic-thermal energy storage hybrid power system with electric heater. Sol. Energy 2020, 195, 138-149. [CrossRef]

14. Attemene, N.S.; Agbli, K.S.; Fofana, S.; Hissel, D. Optimal sizing of a wind, fuel cell, electrolyzer, battery and supercapacitor system for off-grid applications. Int. J. Hydrogen Energy 2020, 45, 5512-5525. [CrossRef]

15. Alsharif, M.; Nordin, R.; Ismail, M. Energy optimisation of hybrid off-grid system for remote telecommunication base station deployment in Malaysia. EURASIP J. Wirel. Commun. Netw. 2015, 64, 1-15. [CrossRef]

16. Aris, A.M.; Shabani, B. Sustainable Power Supply Solutions for Off-Grid Base Stations. Energy 2015, 8, 10904-10941. [CrossRef]

17. Rajanna, S.; Saini, R.P. Development of optimal integrated renewable energy model with battery storage for a remote Indian area. Energy 2016, 111, 803-817. [CrossRef]

18. Samy, M.M.; Elkhouly, H.I.; Barakat, S. Multi-objective optimization of hybrid renewable energy system based on biomass and fuel cells. Int. J. Energy Res. 2020, 45, 8214-8230. [CrossRef]

19. Rosso-Cerón, A.M.; Kafarov, V.; Latorre-Bayona, G.; Quijano-Hurtado, R. A novel hybrid approach based on fuzzy multi-criteria decision-making tools for assessing sustainable alternatives of power generation in San Andrés Island. Renew. Sustain. Energy Rev. 2019, 110, 159-173. [CrossRef]

20. Mytilinou, V.; Kolios, A.J. Techno-economic optimisation of offshore wind farms based on life cycle cost analysis on the UK. Renew. Energy 2019, 132, 439-454. [CrossRef]

21. Ould Amrouche, S.; Rekioua, D.; Rekioua, T.; Bacha, S. Overview of energy storage in renewable energy systems. Int. J. Hydrogen Energy 2016, 41, 20914-20927. [CrossRef]

22. Nordin, N.D.; Rahman, H.A. Comparison of optimum design, sizing, and economic analysis of standalone photovoltaic/battery without and with Hydrogen production systems. Renew. Energy 2019, 141, 107-123. [CrossRef]

23. Available online: tradingeconomics.com (accessed on 21 March 2021).

24. Borowski, P.F. Significance and Directions of Energy Development in African Countries. Energy 2021, 14, 4479. [CrossRef]

25. Borowski, P.F. Adaptation strategy on regulated markets of power companies in Poland. Energy Environ. 2019, 30, 3-26. [CrossRef] 
26. Bakhtiari, H.; Zhong, J.; Alvarez, M. Predicting the stochastic behavior of uncertainty sources in planning a stand-alone renewable energy-based microgrid using Metropolis-coupled Markov chain Monte Carlo simulation. Appl. Energy 2021, $290,116719$. [CrossRef]

27. Bouchekara, H.R.E.-H.; Javaid, M.S.; Shaaban, Y.A.; Shahriar, M.S.; Ramli, M.A.M.; Latreche, Y. Decomposition based multiobjective evolutionary algorithm for PV/Wind/Diesel Hybrid Microgrid System design considering load uncertainty. Energy Rep. 2021, 7, 52-69. [CrossRef]

28. Blazquez, J.; Nezamuddin, N.; Zamrik, T. Economic policy instruments and market uncertainty: Exploring the impact on renewables adoption. Renew. Sustain. Energy Rev. 2018, 94, 224-233. [CrossRef]

29. Ebrahimi, J.; Abedini, M.; Rezaei, M.M.; Nasri, M. Optimum design of a multi-form energy in the presence of electric vehicle charging station and renewable resources considering uncertainty. Sustain. Energy Grids Netw. 2020, 23, 100375. [CrossRef]

30. Li, J.; Huang, S.; Abedinia, O. Investigation in Economic Analysis of Microgrids based on Renewable Energy Uncertainty and Demand Response in the Electricity Market. Energy 2021, 225, 120247.

31. Barati, F.; Jadid, S.; Zangeneh, A. Private investor-based distributed generation expansion planning considering uncertainties of renewable generations. Energy 2019, 173, 1078-1091. [CrossRef]

32. Mirzamohammadi, S.; Jabarzadeh, A.; Shahrabi, M.S. Long-term planning of supplying energy for greenhouses using renewable resources under uncertainty. J. Clean. Prod. 2020, 264, 121611. [CrossRef]

33. Liu, B.; Lund, J.R.; Liao, S.; Jin, X.; Liu, L.; Cheng, C. Optimal power peak shaving using hydropower to complement wind and solar power uncertainty. Energy Convers. Manag. 2020, 209, 112628. [CrossRef]

34. Li, Y.; Zhang, F.; Li, Y.; Wang, Y. An improved two-stage robust optimization model for CCHP-P2G microgrid system considering multi-energy operation under wind power outputs uncertainties. Energy 2021, 223, 120048. [CrossRef]

35. Tan, Q.; Wen, X.; Sun, Y.; Lei, X.; Wang, Z.; Qin, G. Evaluation of the risk and benefit of the complementary operation of the large wind-photovoltaic-hydropower system considering forecast uncertainty. Appl. Energy 2021, 285, 116442. [CrossRef]

36. Ezbakhe, F.; Pérez-Foguet, A. Decision analysis for sustainable development: The case of renewable energy planning under uncertainty. Eur. J. Oper. Res. 2021, 291, 601-613. [CrossRef]

37. Fitiwi, D.Z.; Lynch, M.; Bertsch, V. Power system impacts of community acceptance policies for renewable energy deployment under storage cost uncertainty. Renew. Energy 2020, 156, 893-912. [CrossRef]

38. Scott, I.J.; Botterud, A.; Carvalho, P.M.S.; Silva, C.A.S. Renewable energy support policy evaluation: The role of long-term uncertainty in market modelling. Appl. Energy 2020, 278, 115643. [CrossRef]

39. Tsao, Y.-C.; Thanh, V.-V. Toward blockchain-based renewable energy microgrid design considering default risk and demand uncertainty. Renew. Energy 2021, 163, 870-881. [CrossRef]

40. Yang, J.; Su, C. Robust optimization of microgrid based on renewable distributed power generation and load demand uncertainty. Energy 2021, 223, 120043. [CrossRef]

41. Wang, C.; Zhang, Z.; Abedinia, O.; Farkoush, S.G. Modeling and analysis of a microgrid considering the uncertainty in renewable energy resources, energy storage systems and demand management in electrical retail market. J. Energy Storage 2021, $33,102111$. [CrossRef]

42. Xu, H.; Meng, Z.; Wang, Y. Economic dispatching of microgrid considering renewable energy uncertainty and demand side response. Energy Rep. 2020, 6, 196-204. [CrossRef]

43. Yuan, W.; Liu, Z.; Su, C.; Wang, X. Photovoltaic capacity optimization of small and medium-sized hydro-photovoltaic hybrid energy systems considering multiple uncertainties. J. Clean. Prod. 2020, 276, 124170. [CrossRef]

44. Zhang, H.; Hu, X.; Cheng, H.; Zhang, S.; Hong, S.; Gu, Q. Coordinated scheduling of generators and tie lines in multi-area power systems under wind energy uncertainty. Energy 2021, 222, 119929. [CrossRef]

45. Zhang, Y.; Gu, C.; Yan, X.; Li, F. Cournot oligopoly game-based local energy trading considering renewable energy uncertainty costs. Renew. Energy 2020, 159, 1117-1127. [CrossRef]

46. Zhang, Z.; Qin, H.; Li, J.; Liu, Y.; Yao, L.; Wang, Y.; Wang, C.; Pei, S.; Zhou, J. Short-term optimal operation of wind-solar-hydro hybrid system considering uncertainties. Energy Convers. Manag. 2020, 205, 112405. [CrossRef]

47. Zhu, F.; Zhong, P.A.; Xu, B.; Liu, W.; Wang, W.; Sun, Y.; Chen, J.; Li, J. Short-term stochastic optimization of a hydro-windphotovoltaic hybrid system under multiple uncertainties. Energy Convers. Manag. 2020, 214, 112902. [CrossRef]

48. Olatomiwa, L.; Mekhilef, S.; Huda, A.S.N.; Ohunakin, O.S. Economic evaluation of hybrid energy systems for rural electrification in six geo-political zones of Nigeria. Renew. Energy 2015, 83, 435-446. [CrossRef]

49. Olatomiwa, L.; Mekhilef, S.; Huda, A.S.N.; Sanusi, K. Techno-economic analysis of hybrid PV-diesel-battery and PV-winddiesel-battery power systems for mobile BTS: The way forward for rural development. Energy Sci. Eng. 2015, 3, $271-285$. [CrossRef]

50. Brenna, M.; Foiadelli, F.; Longo, M.; Abegaz, T.D. Integration and Optimization of Renewables and Storages for Rural Electrification. Sustainability 2016, 8, 982. [CrossRef]

51. Isa, N.M.; Das, H.S.; Tan, C.W.; Yatim, A.H.M.; Lau, K.Y. A techno-economic assessment of a combined heat and power photovoltaic/fuel cell/battery energy system in Malaysia hospital. Energy 2016, 112, 75-90. [CrossRef]

52. Singh, A.; Baredar, P. Techno-economic assessment of a solar PV, fuel cell, and biomass gasifier hybrid energy system. Energy Rep. 2016, 2, 254-260. [CrossRef] 
53. Singh, S.; Singh, M.; Kaushik, S.C. Feasibility study of an islanded microgrid in rural area consisting of PV, wind, biomass and battery energy storage system. Energy Convers. Manag. 2016, 128, 178-190. [CrossRef]

54. Das, B.K.; Hoque, N.; Mandal, S.; Pal, T.K.; Raihan, M.A. A techno-economic feasibility of a stand-alone hybrid power generation for remote area application in Bangladesh. Energy 2017, 134, 775-788. [CrossRef]

55. Das, H.S.; Tan, C.W.; Yatim, A.H.M.; Lau, K.Y. Feasibility analysis of hybrid photovoltaic/battery/fuel cell energy system for an indigenous residence in East Malaysia. Renew. Sustain. Energy Rev. 2017, 76, 1332-1347. [CrossRef]

56. Khemariya, M.; Mittal, A.; Baredar, P.; Singh, A. Cost and size optimization of solar photovoltaic and fuel cell based integrated energy system for un-electrified village. J. Energy Storage 2017, 14, 62-70. [CrossRef]

57. Rajbongshi, R.; Borgohain, D.; Mahapatra, S. Optimization of PV-biomass-diesel and grid base hybrid energy systems for rural electrification by using HOMER. Energy 2017, 126, 461-474. [CrossRef]

58. Shahzad, M.K.; Zahid, A.; ur Rashid, T.; Rehan, M.A.; Ali, M.; Ahmad, M. Techno-economic feasibility analysis of a solar-biomass off grid system for the electrification of remote rural areas in Pakistan using HOMER software. Renew. Energy 2017, 106, 264-273. [CrossRef]

59. Ahmad, J.; Imran, M.; Khalid, A.; Iqbal, W.; Ashraf, S.R.; Adnan, M.; Ali, S.F.; Khokhar, K.S. Techno economic analysis of a wind-photovoltaic-biomass hybrid renewable energy system for rural electrification: A case study of Kallar Kahar. Energy 2018, 148, 208-234. [CrossRef]

60. Duman, A.C.; Güler, Ö. Techno-economic analysis of off-grid PV/wind/fuel cell hybrid system combinations with a comparison of regularly and seasonally occupied households. Sustain. Cities Soc. 2018, 42, 107-126. [CrossRef]

61. Dursun, B.; Aykut, E. An investigation on wind/PV/fuel cell/battery hybrid renewable energy system for nursing home in Istanbul. Proc. Inst. Mech. Eng. Part A J. Power Energy 2019, 233, 616-625. [CrossRef]

62. Gebrehiwot, K.; Mondal, M.A.H.; Ringler, C.; Gebremeskel, A.G. Optimization and cost-benefit assessment of hybrid power systems for off-grid rural electrification in Ethiopia. Energy 2019, 177, 234-246. [CrossRef]

63. Groppi, D.; Astiaso Garcia, D.; Lo Basso, G.; Cumo, F.; De Santoli, L. Analysing economic and environmental sustainability related to the use of battery and Hydrogen energy storages for increasing the energy independence of small islands. Energy Convers. Manag. 2018, 177, 64-76. [CrossRef]

64. Karmaker, A.K.; Ahmed, M.R.; Hossain, M.A.; Sikder, M.M. Feasibility assessment \& design of hybrid renewable energy based electric vehicle charging station in Bangladesh. Sustain. Cities Soc. 2018, 39, 189-202.

65. Khare, V.; Nema, S.; Baredar, P. Optimisation of the hybrid renewable energy system by HOMER, PSO and CPSO for the study area. Int. J. Sustain. Energy 2017, 36, 326-343. [CrossRef]

66. Pavan Kumar, Y.V.; Bhimasingu, R. Renewable energy based microgrid system sizing and energy management for green buildings. J. Mod. Power Syst. Clean Energy 2015, 3, 1-13. [CrossRef]

67. Baneshi, M.; Hadianfard, F. Techno-economic feasibility of hybrid diesel/PV/wind/battery electricity generation systems for nonresidential large electricity consumers under southern Iran climate conditions. Energy Convers. Manag. 2016, 127, 233-244. [CrossRef]

68. Li, C.; Zhou, D.; Zheng, Y. Techno-economic comparative study of grid-connected PV power systems in five climate zones, China. Energy 2018, 165, 1352-1369. [CrossRef]

69. Mandal, S.; Das, B.K.; Hoque, N. Optimum sizing of a stand-alone hybrid energy system for rural electrification in Bangladesh. J. Clean. Prod. 2018, 200, 12-27. [CrossRef]

70. Olatomiwa, L.; Blanchard, R.; Mekhilef, S.; Akinyele, D. Hybrid renewable energy supply for rural healthcare facilities: An approach to quality healthcare delivery. Sustain. Energy Technol. Assess. 2018, 30, 121-138. [CrossRef]

71. Oulis Rousis, A.; Tzelepis, D.; Konstantelos, I.; Booth, C.; Strbac, G. Design of a Hybrid AC/DC Microgrid Using HOMER Pro: Case Study on an Islanded Residential Application. Invention 2018, 3, 55. [CrossRef]

72. Robert, F.C.; Gopalan, S. Low cost, highly reliable rural electrification through a combination of grid extension and local renewable energy generation. Sustain. Cities Soc. 2018, 42, 344-354. [CrossRef]

73. Abdin, Z.; Mérida, W. Hybrid energy systems for off-grid power supply and Hydrogen production based on renewable energy: A techno-economic analysis. Energy Convers. Manag. 2019, 196, 1068-1079. [CrossRef]

74. Abnavi, M.D.; Mohammadshafie, N.; Rosen, M.A.; Dabbaghian, A.; Fazelpour, F. Techno-economic feasibility analysis of standalone hybrid wind/photovoltaic/diesel/battery system for the electrification of remote rural areas: Case study Persian Gulf Coast-Iran. Environ. Prog. Sustain. Energy 2019, 38, 13172. [CrossRef]

75. Das, B.K.; Al-Abdeli, Y.M.; Woolridge, M. Effects of battery technology and load scalability on stand-alone PV/ICE hybrid micro-grid system performance. Energy 2019, 168, 57-69. [CrossRef]

76. Kumar, K.; Alam, M.; Dutta, V. Techno-economic analysis of metal hydride-based energy storage system in microgrid. Energy Storage 2019, 1, e62. [CrossRef]

77. Li, C. Techno-economic study of off-grid hybrid photovoltaic/battery and photovoltaic/battery/fuel cell power systems in Kunming, China. Energy Sources Part A Recovery Util. Environ. Eff. 2019, 41, 1588-1604. [CrossRef]

78. Li, C.; Zhou, D.; Wang, H.; Cheng, H.; Li, D. Feasibility assessment of a hybrid PV/diesel/battery power system for a housing estate in the severe cold zone-A case study of Harbin, China. Energy 2019, 185, 671-681. [CrossRef]

79. Luta, D.N.; Raji, A.K. Optimal sizing of hybrid fuel cell-supercapacitor storage system for off-grid renewable applications. Energy 2019, 166, 530-540. [CrossRef]

80. Marino, C.; Nucara, A.; Panzera, M.F.; Pietrafesa, M.; Varano, V. Energetic and economic analysis of a stand alone photovoltaic system with Hydrogen storage. Renew. Energy 2019, 142, 316-329. [CrossRef] 
81. Muh, E.; Tabet, F. Comparative analysis of hybrid renewable energy systems for off-grid applications in Southern Cameroons. Renew. Energy 2019, 135, 41-54. [CrossRef]

82. Murugaperumal, K.; Ajay DVimal Raj, P. Feasibility design and techno-economic analysis of hybrid renewable energy system for rural electrification. Sol. Energy 2019, 188, 1068-1083. [CrossRef]

83. Razmjoo, A.; Davarpanah, A. Developing various hybrid energy systems for residential application as an appropriate and reliable way to achieve Energy sustainability. Energy Sources Part A Recovery Util. Environ. Eff. 2019, 41, 1180-1193. [CrossRef]

84. Tiwary, A.; Spasova, S.; Williams, I.D. A community-scale hybrid energy system integrating biomass for localised solid waste and renewable energy solution: Evaluations in UK and Bulgaria. Renew. Energy 2019, 139, 960-967. [CrossRef]

85. Arévalo, P.; Benavides, D.; Lata-García, J.; Jurado, F. Energy control and size optimization of a hybrid system (photovoltaichidrokinetic) using various storage technologies. Sustain. Cities Soc. 2020, 52, 101773. [CrossRef]

86. Azerefegn, T.M.; Bhandari, R.; Ramayya, A.V. Techno-economic analysis of grid-integrated PV/wind systems for electricity reliability enhancement in Ethiopian industrial park. Sustain. Cities Soc. 2020, 53, 101915. [CrossRef]

87. Temiz, M.; Javani, N. Design and analysis of a combined floating photovoltaic system for electricity and Hydrogen production. Int. J. Hydrogen Energy 2020, 45, 3457-3469. [CrossRef]

88. Vendoti, S.; Muralidhar, M.; Kiranmayi, R. Techno-economic analysis of off-grid solar/wind/biogas/biomass/fuel cell/battery system for electrification in a cluster of villages by HOMER software. Environ. Dev. Sustain. 2020, 23, 351-372. [CrossRef]

89. Available online: Wikipedia.com (accessed on 11 February 2021).

90. Available online: www.amar.org.ir (accessed on 19 February 2021).

91. Sinha, S.; Chandel, S.S. Review of software tools for hybrid renewable energy systems. Renew. Sustain. Energy Rev. 2014, 32, 192-205. [CrossRef]

92. Vaziri Rad, M.A.; Ghasempour, R.; Rahdan, P.; Mousavi, S.; Arastounia, M. Techno-economic analysis of a hybrid power system based on the cost-effective Hydrogen production method for rural electrification, a case study in Iran. Energy 2020, $190,116421$.

93. Razmjoo, A.; Gakenia Kaigutha, L.; Vaziri Rad, M.A.; Marzband, M.; Davarpanah, A.; Denai, M.A. Technical analysis investigating energy sustainability utilizing reliable renewable energy sources to reduce $\mathrm{CO} 2$ emissions in a high potential area. Renew. Energy 2021, 164, 46-57. [CrossRef]

94. Yimen, N.; Hamandjoda, O.; Meva'a, L.; Ndzana, B.; Nganhou, J. Analyzing of a Photovoltaic/Wind/Biogas/Pumped-Hydro Off-Grid Hybrid System for Rural Electrification in Sub-Saharan Africa-Case Study of Djoundé in Northern Cameroon. Energy 2018, 11, 2644. [CrossRef]

95. Kasaeian, A.; Rahdan, P.; Rad, M.A.V.; Yan, W.-M. Optimal design and technical analysis of a grid-connected hybrid photovoltaic/diesel/biogas under different economic conditions: A case study. Energy Convers. Manag. 2019, 198, 111810. [CrossRef]

96. HOMER. The HOMER Pro ${ }^{\circledR}$ Microgrid Software. Available online: http:/ / www.homerenergy.com (accessed on 16 December 2020).

97. Akhtari, M.R.; Baneshi, M. Techno-economic assessment and optimization of a hybrid renewable co-supply of electricity, heat and Hydrogen system to enhance performance by recovering excess electricity for a large energy consumer. Energy Convers. Manag. 2019, 188, 131-141. [CrossRef]

98. Rezaei, M.; Naghdi-Khozani, N.; Jafari, N. Wind energy utilization for Hydrogen production in an underdeveloped country: An economic investigation. Renew. Energy 2020, 147, 1044-1057. [CrossRef]

99. Rezaei, M.; Khalilpour, K.R.; Jahangiri, M. Multi-criteria location identification for wind/solar based Hydrogen generation: The case of capital cities of a developing country. Int. J. Hydrogen Energy 2020, 45, 33151-33168. [CrossRef]

100. Singh, A.; Baredar, P.; Gupta, B. Techno-economic feasibility analysis of Hydrogen fuel cell and solar photovoltaic hybrid renewable energy system for academic research building. Energy Convers. Manag. 2017, 145, 398-414. [CrossRef]

101. Krishnan, K.J.; Kalam, A.; Zayegh, A. Experimental Investigation of H2 Generator and PEM Fuel Cell as a Remote Area Back-Up Power. Procedia Eng. 2012, 49, 66-73. [CrossRef]

102. Chong, L.W.; Wong, Y.W.; Rajkumar, R.K.; Rajkumar, R.K.; Isa, D. Hybrid energy storage systems and control strategies for stand-alone renewable energy power systems. Renew. Sustain. Energy Rev. 2016, 66, 174-189. [CrossRef]

103. Ghenai, C.; Bettayeb, M. Modelling and performance analysis of a stand-alone hybrid solar PV/Fuel Cell/Diesel Generator power system for university building. Energy 2019, 171, 180-189. [CrossRef]

104. Bicer, Y.; Dincer, I. Clean fuel options with Hydrogen for sea transportation: A life cycle approach. Int. J. Hydrogen Energy 2018, 43, 1179-1193. [CrossRef]

105. Gupta, A.; Saini, R.P.; Sharma, M.P. Steady-state modelling of hybrid energy system for off grid electrification of cluster of villages. Renew. Energy 2010, 35, 520-535. [CrossRef]

106. Cano, A.; Arévalo, P.; Jurado, F. Energy analysis and techno-economic assessment of a hybrid PV/HKT/BAT system using biomass gasifier: Cuenca-Ecuador case study. Energy 2020, 202, 117727. [CrossRef]

107. Cumalioglu, I.; Ma, Y.; Ertas, A.; Maxwell, T. High Pressure Hydrogen Storage Tank: A Parametric Design Study. J. Press. Vessel. Technol. 2006, 129, 216-222. [CrossRef]

108. Lau, K.Y.; Tan, C.W.; Yatim, A.H.M. Photovoltaic systems for Malaysian islands: Effects of interest rates, diesel prices and load sizes. Energy 2015, 83, 204-216. [CrossRef]

109. Gökçek, M.; Kale, C. Techno-economical evaluation of a Hydrogen refuelling station powered by Wind-PV hybrid power system: A case study for İzmir-Çeşme. Int. J. Hydrogen Energy 2018, 43, 10615-10625. [CrossRef] 